ISSN: 0213-2079 - ISSN electrónico: 2386-3889

DOI: https://doi.org/10.14201/shhmo201840175123

\title{
SANTIDAD Y PATRONAZGO EN EL MUNDO HISPÁNICO DE LA EDAD MODERNA*
}

\section{Holiness and Patronage in the Hispanic World in the Modern Age}

Eliseo SERRANO MARTÍN

Universidad de Zaragoza

Correo-e: eserrano@unizar.es

ORCID: 0000-0003-1150-7467

RESUMEN: El 23 de marzo de 1630 la Congregación de Ritos publicó un decreto sobre Los Santos patronos que limitaba su elección a los canonizados. De esta manera se otorgaba un control directo a la Santa Sede. La elección de las ciudades de sus santos patronos en la Edad Moderna vino determinada por los intereses de sus clases dirigentes, la devoción popular y por la posesión de las reliquias de los propuestos. Sobre la patria de los santos, mártires, obispos y eremitas y el control de sus reliquias se publicaron muchos escritos polémicos que generaron intensos debates durante el siglo Xvir. En la elección de los santos patronos no siempre se respetará la normativa vaticana; en los casos de Pedro Regalado y Rosa de Lima hubo autorizaciones expresas para el inicio de los procesos de canonización, su culto y su nombramiento.

Palabras clave: Santos patronos; reliquias; hagiografía; Pedro Regalado; Rosa de Lima.

* Este trabajo se enmarca en el proyecto de investigación del Ministerio de Ciencia e Innovación HAR2014-52434-C5-2-P del que soy Investigador Principal. El autor es miembro del Grupo de Investigación Blancas, financiado por el Gobierno de Aragón con fondos Feder. 
ABSTRACT: On March 23, 1630 the Congregation of rites issued a decree on the patron saints that limited their choice to the canonized. In this way direct control was granted to the Holy See. The choice of the cities of their patron saints in the modern age was determined by the interests of their ruling classes, the popular devotion and by the possession of the relics of the proposed saints. Concerning to the homeland of the Saints, martyrs, bishops and hermits, and the control of their relics were published many controversial writings that generated intense debates during the 17 th century. In the election of the of the patron saints the Vatican regulation will not always be respected; in the case of Pedro Regalado and Rosa de Lima there were express authorization for the beginning of the canonization processes, his cult and their appointment.

Key words: Patron Saints; relics; hagiography; Pedro Regalado; Rosa de Lima.

El 23 de marzo de 1630 la Congregación de Ritos publicó un decreto, Decretum pro patronis in posterum elegendis ${ }^{1}$, que iba a cambiar el procedimiento seguido hasta ese momento para la elección del santo patrono o santo protector, otorgando un control directo a la sede apostólica. El decreto dejaba claro que solo podían ser elegidos como santos patronos aquellos santos venerados como tales por toda la iglesia universal, «quod eligi possint in patronos ii solum, qui ab ecclesia universali titulo sanctorum coluntur, non autem beatificati dumtaxat»; es decir los ya canonizados o registrados en el martirologio romano. La elección debía hacerse por los representantes institucionales del pueblo reunido en consejo municipal y debía ser confirmada por los oficiales del clero local y el obispo de la diócesis. Finalmente el proceso verbal debía ser examinado por la Congregación de Ritos, que era quien controlaba que las disposiciones de ser santos canonizados y elegidos con la aprobación del obispo se cumplían, «causa cognota, ab eadem congregatione approbari, et confirmari».

Con el decreto de 1630 la práctica seguida para la elección o el culto a un santo patrono era: primero la ciudad o la villa elige, motivada por muchas causas $\mathrm{o}$ intereses, un santo protector, un santo patrono y da comienzo un proceso verbal, un acopio de argumentos; a su vez el clero de la ciudad hace lo mismo y el obispo da su aprobación. Todo ello se remite a la Congregación de Ritos en

1. Decreta Authentica Congregationis Sacrorum Rituum: Ex actis... Tomus Primus, ab anno 1602-1645..., Romae, Typis Francisci et Leopoldi Bourlié, MDCCCXXIV, n. ${ }^{\circ}$ 705, p. 237. 
Roma, que verifica los diferentes pasos dados y pide más información, rechaza o aprueba dicha elección.

Con este decreto quedaron descartados los beatos y santos de dudosa autenticidad. También se ha afirmado que esta innovación normativa incidió en la fortuna diversa de los santos modernos, limitándolos, y de ahí una cierta preferencia por los santos antiguos, los mártires de diversa índole, los ángeles, la Virgen y figuras del Nuevo Testamento².

Que la Congregación de Ritos estuvo muy atenta lo demuestra la anulación de la elección como santo patrono de Nápoles de Andrea Avellino, de Giacomo della Marca en Foggia en 1633 y de Estanislao de Koska en Lecce en 1669, por ser elegidos antes de su canonización. En los años 1625 y 1626 en Nápoles se desarrollaron consecutivamente cuatro elecciones, del beato Andrea Avellino, de santa Patricia, del beato Giacomo della Marca y de san Francisco de Paula. Todavía no existía ninguna restricción y únicamente la Congregación actuaba para acordar el permiso de oficiar la función religiosa de manera particular, de dar culto particular a petición de la ciudad. Y también actuaba en la controversia suscitada entre órdenes por el puesto que debían tener los nuevos santos patronos, decidiendo que Andrea Avellino ocupase el noveno lugar mientras que santa Patricia lo hiciese en el undécimo ${ }^{3}$.

Para Roma la fiesta del santo patrono fue considerada muy importante, por lo que Urbano VIII promulgó una Bula en 1642, Pro observatione festorum ${ }^{4}$ en la que se declaraba fiesta de precepto el día del santo protector y por tanto también un día festivo para los trabajadores.

Ambos decretos, el de 1630 y la bula de 1642, dedicados en exclusividad a los santos patronos, se añadían a una intensa actividad normativa sobre la santidad que desde el Concilio de Trento reforzará el papel del Pontífice y la Inquisición, pero que también tendrá como objetivo defenderse de las críticas de la falsa santidad.

El Concilio de Trento dejaba muy claro cómo se debía proceder en un asunto que claramente diferenciaba al catolicismo de los protestantismos. Efectivamente, los días 3 y 4 de diciembre de 1563, en la sesión XXV del Concilio se aprobó

2. Gotor, M.: Chiesa e santità en l'Italia moderna. Roma-Bari, 2004, p. 104.

3. Sallman, J.-M.: Santi barocchi. Modelli di santità. Pratiche devozionali e comportamenti religiosi nel regno di Napoli dal 1540 al 1750. Lecce, 1996, p. 85.

4. Pro observatione festorum, en Magnum Bullarium Romanum, a beato Leone Magno usque ad S.D.N. Benedictum XIV. Opus Absolutissimum... Tomus Quintus, Romae, ex Typographica Reverenda Camara Apostolica..., MDCCXLII, p. 378; hay edición exenta: Pro observatione festorum cum explanationes ulteriore Ferdinandi Archepiscopi Coloniensis, Coloniae Agrippinae Impressum, MDCXLIII. 
el decreto De invocatione, veneratione et reliquiis sanctorum, et sacris imaginibus, en el que se afirmaba la doctrina católica del culto a los santos frente a las acusaciones protestantes de idolatría. Era el Papa quien tenía la última palabra, pero los obispos podían y debían iniciar y controlar los procesos. Nada se dice sobre la canonización; quedaba como hasta ahora, con la Inquisición y el Papado como garantes de los nuevos santos y este último con plenitudo potestatis, al menos desde Inocencio III (1198-1216)5.

Pronto habrá que ocuparse de la cuestión procedimental y administrativa; en seguida los Papas crearán los instrumentos normativos e institucionales necesarios para el control del acceso a la santidad y la verificación de las reliquias.

El 22 de enero de 1588 el Papa Sixto V Peretti (1585-1590), con la constitución apostólica Inmensa aeterni Dei, dispuso la reorganización de las congregaciones para una mejor y ordenada dirección de la Iglesia, a cuya cabeza visible, el papado, le correspondía dicha dirección, pero con la ayuda de la curia y de los cardenales. La que más nos interesa para el asunto de la santidad es la Congregación para los Ritos y Ceremonias ${ }^{6}$, que perdurará hasta el 8 de mayo de 1969 en que el Papa Pablo VI creará la Congregación para la Causa de los Santos, ocupándose a partir de ese momento de los procesos de canonización. Se fundamentó en la necesidad de aumentar la piedad de los hijos de la Iglesia con la conservación y prácticas de las ceremonias, usos y ritos en orden a la enseñanza para el pueblo cristiano y la profesión de la verdadera fe. Buscaba promover la piedad y elevar el culto divino ${ }^{7}$.

Los Papas posteriores a Trento ahormaron la imagen de la santidad y el modo de conseguirla, fundamentalmente el ya citado Sixto V (1585-1590), Urbano VIII (1623-1644) y Benedicto XIV (1740-1758), quienes organizaron los dicasterios, dictaron normas y firmaron decretos para un mayor rigor procesal, lo que no quiere decir que, como ha escrito Gotor, la fase clementina, por Clemente VIII (1592-1605), y la paulina, por Paulo V (1605-1621), no fuesen determinantes en cuanto a modelos de beatos ${ }^{8}$.

5. XXV Sesión del Concilio de Trento. «De la invocación, veneración y reliquias de los santos y de las sagradas imágenes», en El sacrosanto y ecuménico Concilio de Trento, traducido al idioma castellano por don Ignacio López de Ayala. Agrégase el texto latino según la edición auténtica de Roma, publicada en 1564, Cuarta edición. Con privilegio, Madrid, en la imprenta de Ramón Ruiz, MDCCXCVIII, pp. 355-360, la nota en p. 357.

6. Para el funcionamiento de la Congregación de Ritos, vid., Análisis de la obra de nuestro santísimo Padre Benedicto XIV sobre las beatificaciones y canonizaciones. La escribió en francés Monsieur Nicolás Baudeau... y la traduxo al castellano don Gaspar de la Cruz... Madrid, Pedro Marín, 1779, pp. 37-53.

7. Gotor, M.: Chiesa e santità..., op. cit., pp. 34 y ss.

8. Gotor, M.: I Beati del Papa. Santità, Inquisizione e obbedienza in età moderna. Florencia, Leo S. Olschki, 2002. 
Aunque la organización procedimental de los procesos para la santidad venía de más lejos, fue Urbano VIII ${ }^{9}$ quien estableció las etapas de un proceso ordinario o informativo y de otro apostólico, buscando cierto garantismo ante las críticas, sobre todo por el culto que se daba a personas que no tenían el título de santo. Ese es el sentido del llamado decreto super non cultu; Urbano VIII en sendos decretos del 13 de marzo de 1625, 5 de junio de 1631 y 5 de julio de 1634 prohibió el culto público a una persona antes de ser culto autorizado a través del decreto de canonización.

En el siglo xvir quedó fijado que antes de ser canonizado debía existir un paso previo que era la beatificación. En puridad la beatificación era una dispensa, un indulto particular, un permiso que se daba para dar culto público en una ciudad o por una congregación religiosa a un siervo de Dios. Gotor dice que fue en 1585 cuando surge por primera vez, que el agustino Angelo Roca en su tratado sobre las canonizaciones de 1601 prefiere llamarlo «semicanonización» y con la fundación de la Congregazione dei Beati (por Clemente VIII en 1602) se centraliza este estadio para los candidatos, controlado en su integridad por el Papa y los cardenales de la curia ${ }^{10}$

La autentificación de los milagros, piedra angular de la santidad, fue considerada un problema para la Iglesia. Fue el Papa Benedicto XIV quien más interés puso en promover auténticas investigaciones para evitar certificar con la simple creencia de su verosimilitud el recobrar la salud de enfermedades incurables. Comenzó su obra antes de llegar al pontificado, siendo arzobispo de Bolonia, editando De servorum Dei beatificatione et beatorum canonizatione $e^{11}$ por primera vez entre 1734 y 1738, habiendo posteriormente unas cuantas ediciones más y para la que se sirvió de su larga experiencia de más de treinta años en la Congregación de Ritos. En su obra propone una santidad heroica, virtuosa y equilibrada contrastada con la mística y con una nueva revaluación de la misma.

9. Pastor, L.: Historia de los Papas en la época de la Reforma y Restauración católica. Vol. XXI, Sixto V (1585-1590), Vol. XXII, Final del Papado de Sixto V; Urbano VII, Gregorio XIV e Inocencio IX (1585-1591). Barcelona, Gustavo Gili, 1941, lo relacionado con las Congregaciones en vol. XXI, pp. 223-236, la cita en p. 225, vol. XXVII-XXVIII-XXIX, (Urbano VIII, 1623-1644); Dalla Torre, G.: Santità e diritto. Sondaggi nella storia del diritto canonico. Turín, 1999, pp. 27-81; Gotor, M.: I beati del papa..., op. cit., pp. 285-320.

10. Gотоr, M.: Chiesa e santità..., op. cit., p. 47. También Gotor, M.: I Beati del papa..., op. cit., pp. 127-254.

11. Benedicto XIV Pont. Opt. Max. Doctrinam de servorum Dei Beatificatione et beatorum Canonizatione redactam in synopsim Emmanuel de Azevedo auctori suo magistro, ac patrono. D.D.P., Romae MDCCLVII, Typis Generosi Salomoni Bibliopolae superiore permissu. 


\section{El culto al santo patrono. Corografía, historia, hagiografía}

El culto de los santos patronos nos presenta una diversa casuística en la elección de los mismos por parte de los fieles, las congregaciones, las ciudades o los países. Desde la invocación de la protección de los mártires antiguos cuyas reliquias conservan, cuerpos santos de especial veneración nuevamente valorados en los siglos de la contrarreforma, hasta los puestos por intereses sociales y políticos por parte de las elites, son muchos los santos que en los siglos modernos son señalados como protectores. En la construcción del santo patrono en una ciudad intervienen complicadas relaciones de poder e influencia. Es necesario tener en cuenta la dinámica de las elites ciudadanas, el papel desempeñado por las órdenes religiosas y los capítulos eclesiásticos, la publicística y confrontación con otros lugares, la religiosidad y sus formas complejas, en fin, un continuo y abigarrado mundo de referencias, dinámicas de poder y elaboración teórica sobre la intercesión de quienes son elegidos como protectores o patronos.

Francisco Rodríguez en su Breve compendio de las grandezas del reyno de Aragón $n^{12}$, además de referirse a las imágenes aparecidas de la Virgen, recoge vidas de santos aragoneses y de aquellos cuyas reliquias descansan en el territorio señalando 51 más los denominados Innumerables enterrados en la cripta de santa Engracia. Muchos de los que cita son patronos de ciudades y localidades aragonesas a cuyo patrocinio se fueron acogiendo desde la Edad Media. Son los casos de santa Engracia y san Valero, ambos patronos de Zaragoza, la primera desde el siglo xv y el segundo vinculado a la catedral zaragozana desde el siglo XII. De Huesca es patrono san Lorenzo, de Calatayud san Íñigo, de Torrehermosa san Pascual Baylón (aunque cuando escribe Rodríguez solo es beato, ya que fue canonizado en 1690 por Alejandro VIII), de Cetina san Juan Lorenzo, de Tarazona san Atilano y san Gaudioso, de Zuera san Glicerio o de Jaca santa Orosia. Falta sin duda un estudio profundo de los patronazgos, de la elección de patronos durante la Edad Moderna en donde dilucidar los aspectos de culto y culturales que llevaron a dicha elección, porque algunos no tienen el título de santo canonizado. Para el reino de Nápoles hace años que fue publicado un estudio sobre la santidad barroca con especial atención a los santos patronos y la protección colectiva ${ }^{13}$. En dicho estudio, entre 1630 y 1750 fueron 225 las ciudades y otras instituciones las que eligieron 410 nuevos santos patronos en 347 elecciones, de acuerdo a la nueva normativa de marzo de 1630, con lo que se manifiesta que Nápoles supera a todas las regiones

12. Rodríguez, F.: Breve compendio de las grandezas del reyno de Aragon. Roma, Imprenta de la Reverenda Cámara Apostólica, 1685.

13. Sallman, J.-M.: Santi barocchi..., op. cit., esp. pp. 84-120. 
de la península en cuanto al dinamismo en el culto de los santos. Y ni que decir tiene que Italia está a la cabeza de los países católicos. A finales del siglo Xvi la mayor parte de las ciudades o de los territorios tienen uno o más santos patronos.

San Isidro es un buen ejemplo de santo «fabricado» con unos intereses claros para la Monarquía, con recursos a la veneración de sus reliquias conservadas y apología de vida heroica y milagrosa a través de la literatura. Fue celebrado por primera vez como patrón de Madrid ${ }^{14}$, y reconocido por el Papado, el 15 de mayo de 1620, con una procesión general, un castillo de fuegos artificiales, una máscara y un certamen poético organizado por Lope de Vega ${ }^{15}$ en el que se cantaron los milagros del patrón, pero también a Madrid como madre de santos, a su escudo y a las grandezas de la villa y Corte. Para María José del Río,

la configuración del primer panteón de patronos urbanos, en el contexto de incertidumbre sobre el papel de la ciudad como capital permanente, presenta una Villa ansiosa por mantener o recuperar su gloria como Corte, pero también una Villa que optaba temporalmente por construirse una identidad con rasgos que le permitieran valorarse por sí misma y afrontar la inseguridad de su destino. Y estos rasgos se los proporcionaron los santos patronos, cuya historia reescrita les permitió encapsular la historia legendaria de la ciudad, sus valores y sus aspiraciones ${ }^{16}$.

Al patrono se le exprime su poder religioso y simbólico, se le muestra con todo su esplendor en su elección prodigiosa del lugar donde se le venera y, en la mayor parte de las ocasiones, se conservan sus reliquias. Porque se trata de hacer ver que las ciudades han sido elegidas por estos protectores, por estos curadores o terapeutas de la vida ciudadana. Sin duda alguna los santos patronos cumplirán a la perfección la demanda de las ciudades y villas, de las comunidades locales y territoriales de identidades propias que fuesen prestigiosas y que contasen con la aprobación y el beneplácito divinos. Estos santos patronos, sus reliquias, milagros y

14. Río, M. ${ }^{a}$ J. del: Madrid, urbs regia. La capital ceremonial de la Monarquía Católica. Madrid, 2000, pp. 83-118; SAEZ, R.: «El culto a san Isidro labrador o la invención y triunfo de una amplia operación político religiosa (1580-1622)», en VITSE, M. (ed.): Homenaje a Henri Guerreiro: la hagiografía entre historia y literatura en la España de la Edad Media y del Siglo de Oro. Madrid, 2005, pp. 1033-1045; Río, M. ${ }^{a}$ J. del: «Agiografia e cronaca di una capitale incerta (Madrid e Isidro labrador, 1590-1620)», en Fiume, G. (ed.): Il santo patrono e la città. San Bernedetto il Moro: culti, devozioni, strategie di età moderna, Venecia, Marsilio, 2000, pp. 45-67.

15. Lope DE VEGA, Justa poética y alabanzas justas que bizo la insigne Villa de Madrid al bienaventurado San Isidro en las fiestas de su Beatificación, Madrid, 1620. Luego escribiría Relacion de las fiestas que la insigne villa de Madid bizo a la canonización de su... patron san Isidro, con las comedias... y los versos que en la Iusta poetica se escrivieron, Madrid, viuda de Alonso Martin, 1622.

16. Río, M. J. del: Madrid, urbs regia..., op cit., p. 118. 
hagiografías serán solicitados, aupados y venerados por esas comunidades locales, pero también serán disputados por patrias y naciones que verán de este modo reafirmada su identidad y reconocida su antigüedad. Y la relación encomiástica entre ciudad y santo se manifestará de manera clara en las corografías, en las historias generales y en la hagiografía y en el género de los Flos o Vidas de santos que adquirieron en la Edad Moderna una gran pujanza.

Con orígenes en la Geografía de Tolomeo las corografías permiten un retrato ajustado de muchos elementos particulares de un determinado lugar. Son para muchos historias locales ${ }^{17}$ con un especial interés por las antigüedades. En el siglo Xvi estuvo de moda en toda Europa y en España pronto se convertirá en un género muy importante ${ }^{18}$, señalando una dirección hacia las historias generales muy necesarias en la política real de propaganda, sobre todo en el siglo Xvir. Su desarrollo fue debido al mecenazgo de los regimientos y concejos de villas y ciudades, a sus elites políticas y religiosas, que impulsaron estas ediciones, las sufragaron y pusieron en sus frontispicios las grandezas y hazañas de estos lugares, siempre elegidos por la Divinidad. La mayoría de los autores eran eruditos locales que sentían amor por su patria, escribían también por motivos políticos y no dudaron en inventar hechos si así defendían mejor el honor y la grandeza de sus localidades, si de este modo pudieran ser considerados importantes en el devenir de la historia de su reino o de España, y no vacilaron en rivalizar abiertamente por vecindad o afirmación de sus propias identidades ${ }^{19}$. Todas ellas participarán de esas descripciones del territorio y de sus característicos paisajes y edificios, de los orígenes míticos (Túbal, Hércules y mitologías varias), de ser patria de los esforzados primeros cristianos y de mártires de quienes poseen sus cuerpos santos con especiales efectos benéficos para la ciudad y su tierra, de ser ejemplo de fidelidad a la monarquía y al tiempo defensor de privilegios y mercedes que les hacer ser únicos. Pero el mercado de las corografías era reducido: pocos ejemplares de las ediciones y un círculo lector también reducido, en este caso a lo local, por lo que puede deducirse que las elites ciudadanas con estas ediciones buscaban instruir a una clientela local sobre las

17. Argensola, B. L.: «Sobre las cualidades que ha de tener un perfecto cronista», en Obras sueltas de Lupercio y Bartolome Leonardo de Argensola, ed. Conde de la Viñaza. Madrid, 1889, t. II, p. 259.

18. Kagan, R.: Los cronistas y la Corona. La politica de la Historia en la España de las Edades Media y Moderna. Madrid, 2010; id.: «La corografía en la Castilla moderna: género, historia, nación», en Arellano, I.; Pinillos, M. C.; Serralta, F. y Vitse, M. (eds.): Studia Aurea. Actas III Congreso de la AISO, Toulouse-Pamplona, 1996, 1, pp. 79-91.

19. Gómez Zorraquino, J. I.: «Los santos patronos y la identidad de las comunidades locales», en Serrano, E. (ed.): «Fábrica de santos. España, siglos Xvi-XviI», Jerónimo Zurita, 85,2010 , pp. 39-74. 
grandezas de su ciudad que se amplifica con sermones, fiestas, espectáculos teatrales... A ello contribuyeron con notable éxito los santos locales. Con la inclusión de muchos de los santos patronos buscan justificar primacías eclesiásticas debido a las predicaciones jacobeas o el carácter apostólico del primitivo cristianismo en la península. En el siglo Xvin la obra de referencia va a ser la Historia de España de Juan de Ferreras ${ }^{20}$, Synopsis historica cronológica de España: Formada de los autores seguros de buena $f e .{ }^{21}$, que cambiará de título a lo largo de sus múltiples ediciones. Criticó y consideró falsos los cronicones de Beroso difundidos por Juan de Viterbo, Dextro, Auberto y una lista de reyes de España tomada de un Juliano Diácono, griego de dudosa historicidad ${ }^{22}$. Ferreras se alinea con una primera corriente de «crítica histórica» ${ }^{23}$, si se le puede llamar así, en la que prevalece un cierto rigor en la búsqueda de fuentes y diplomas medievales sobre todo y cuyos representantes más significativos recibieron sus alabanzas e incluso defensas de su método ${ }^{24}$, especialmente Jean Mabillon (1639-1707) ${ }^{25}$.

Antes de esta Historia de España de Ferreras es necesario referirse a las historias, auspiciadas e interesadas por la Corona como forma de expresar la Monarquía compuesta y el futuro de unidad de los reinos de España. El paso de

20. Valderas, A.: Bibliografía histórica leonesa: Juan de Ferreras García (1652/1735): estudio bio-bibliográfico. León, Universidad, 2000. Uno de sus críticos, Francisco Berganza (1663-1738) escribió sobre su posición frente a los cronicones, vid. Berganza, F.: Ferreras convencido, con crítico desengaño, en el tribunal de los doctos, con los chronicones corregidos... Madrid, Imprenta de Francisco de Hierro, 1729.

21. Serrano Martín, E.: «Silentium facite. El final de la polémica y el discurso en torno a la Virgen del Pilar», Hispania, 248, 2014, pp. 687-714; Ferreras, J. de: Historia de España. Parte diez y seis. Madrid, s.n, s.a., pero 1727; en una edición de 1775.

22. Valderas, A.: Bibliografía histórica leonesa..., op. cit., p. 581; Godoy Alcántara, J.: Historia de los falsos cronicones. Madrid, 1868 [Edición facsímil, Madrid, 1981]; Caro Baroja, J.: Las falsificaciones en la Historia. Barcelona, 1981; Román, J.: Repúblicas del mundo divididas en XXVII libros ordenadas por el f. Hieronymo Roman, frayle profeso y cronista de la Orden de san Agustín, natural de la ciudad de Logroño... Medina del Campo, Francisco del Canto, 1575; SÁnchez FerRa, A. J.: «El logroñés Jerónimo Román y su obra sobre las Repúblicas del mundo", Cuadernos de Investigación: Historia, T. 10, fasc. 1, 1984, pp. 307-316.

23. Mestre, A.: Humanismo y crítica histórica en los ilustrados alicantinos. Alicante, 1980. Algunos de los citados en pp. 17 y ss. También Mestre, A.: «Conciencia histórica e Historiografía», en Jover, J. M. (ed.): Historia de España. Vol. XXXI-1, Madrid, 1987, pp. 302-345, en pp. 313-314.

24. Valderas, A.: Bibliografía histórica leonesa..., op. cit., p. 572.

25. Mabillon, J.: Tratado de los estudios monásticos, divididos en tres partes..., compuestos en frances por... Juan Mabillon, monge benedictino de la Congregacion de San Mauro; traducido en castellano por un monge español de la Congregacionde San Benito de Valladolid, T. I y II. Madrid, Viuda de Mateo Blanco, 1715. [Hay ediciones de 1775 y 1779; esta última impresa por Blas Roman]. 
los cronistas medievales a los «historiadores» de la Modernidad y sus aportaciones en el conjunto de la historiografía europea y española ha sido estudiado de forma reiterada recientemente ${ }^{26}$

La primera historia moderna general de España ${ }^{27}$ fue la de Esteban de Garibay (Mondragón 1533-Toledo 1599) ${ }^{28}$. Heredero de las tradición humanística, su intención fue escribir una historia de los territorios (España) que en ese momento pertenecían al monarca (excluído por tanto Portugal). El mismo anuncia en su obra que es una historia superior a las crónicas, que su historia era la conjunción de las historias de todos los reinos que de modo independiente se habían hecho. Hace una yuxtaposición de historias. Pero aun siendo importante el acopio de fuentes documentales de archivo su escritura en asuntos religiosos y eclesiásticos mantiene las deudas con la acción milagrosa de santos y mártires y la aceptación acrítica de listados episcopales, erección de iglesias y capillas y cultos diversos. Por supuesto acepta la predicación apostólica y la difusión del cristianismo de raíz santiaguista. De dos historias reconoce préstamos significativos, de la del canónigo zamorano Florian de Ocampo (c. 1499-1558)29 y del aragonés Jerónimo Zurita ${ }^{30}$. En esos años hay intentos importantes: Juan Vaseo con su Rerum Hispanicarum Chronicon ${ }^{31}$, Pedro Antonio Beuter ${ }^{32}$, la Chronica d'España de Francesc Tarafa ${ }^{33}$,

26. Kagan, R.: Los cronistas y la Corona..., op. cit.; García Cárcel, R. (coord.): La construcción de las Historias de España. Madrid, 2004.

27. Cuart, B.: «La larga marcha hacia las historias de España en el siglo XVI», en García CÁrcel, R. (coord.): La construcción..., op. cit., pp. 45-126, esp. pp. 110-124.

28. Garibay, E. de: Los XL libros del compendio historial de las Chronicas y universal historia de todos los reynos de España / compuesta por... Amberes, Cristobal Plantino, 1571; Alvar EzQuerra, A.: «Esteban de Garibay: doce claves y alguna relectiones para entender como paralizó la renovación historiográfica española», Revista de Historiografía, 15, 2011, pp. 90-97.

29. Ocampo, F. de: Los cinco primeros libros de la Coronica General de España... Medina del Campo, Guillermo Millis, 1553. Hay otra edición en Alcalá, Juan Íñiguez de Lequerica, a costa de Diego Martínez, 1578; Ocampo, F. de: Los cinco libros postreros de la Coronica General de España / que continuava Ambrosio de Morales... Córdoba, Gabriel Ramos, a costa de Francisco Roberte, 1586; La Coronica General de España / que continuava Ambrosio de Morales... Alcalá, Juan Íñiguez de Lequerica, 1574.

30. Zurita, J.: Anales de Aragón, Edición de Ángel Canellas. Zaragoza, IFC, 1967-1977, 8 vols. [Hay edición en red, en Biblioteca Virtual de la IFC].

31. VASeO, J.: Chronicum Rerum Memorabilium Hispaniae, Salmanticae, Ioannes Iunta, 1552.

32. Beuter, P. A.: Primera parte de la Coronica General de toda España y especialmente del reyno de Valencia... Valencia, Joan de Mey Flandro, 1546, lib. I, c. 23. Sobre la importancia de Beuter, Rausell, H.: «La espiritualidad de Pedro Antonio Beuter: erasmismo y corrientes de reforma", Estudis, 23, 1997, pp. 41-75.

33. Tarafa, F.: Chronica de España del canonigo Francisco Tarapha barcelonés, del origen de los Reyes y cosas señaladas della y varones illustres. Traduzida de lengua latina en castellana. 
Lucio Marineo Sículo ${ }^{34}$ y otros que servirán a posteriores historias de una manera $\mathrm{u}$ otra $^{35}$. Todos ellos serán referencia a la hora de defender los patronatos locales.

El referente por excelencia de la Historia de España durante dos siglos fue la Historia del jesuita Juan de Mariana, editada en Toledo en 1592 con el título Historiae de rebus Hispaniae Libri XX, nuevamente publicada en 1595 con la adición de cinco libros más y ya, traducida al español en dos volúmenes, con el título Historia General de España en $1601^{36}$. Aunque fue acusado de dar crédito a historiadores poco fiables y de aceptar la cronología bíblica o los milagros, la obra de Mariana puede ser considerada una síntesis en la que fue encajando todo con precisión y para ello se sirvió de la obra de muchos españoles que escribieron crónicas o historias parciales, pero también de las obras del inglés Nicolás Sanders, de Ceare Baronio o de Juan Pedro Maffei ${ }^{37}$. Los continuadores de Mariana fueron muchos. Con los novatores y los seguidores de bolandistas y maurinos (Manuel Martí, José Joaquín de Lorga, José Rodríguez, José Manuel Miñana, Nicolás Jesús Belando, Gregorio Mayans, Saénz de Aguirre, Nicolás Antonio, el conde Móndejar) se establece un nuevo método para construir una nueva Historia de España: la crítica documental, el abandono de los falsos cronicones o el uso de los documentos originales. En este contexto surgió la obra de Ferreras, citado anteriormente, que fue acusado de querer acabar con las tradiciones de la Historia de España al rechazar la predicación de Santiago, la venida de la Virgen del Pilar a Zaragoza, la patria y fundación de san Millán y que la victoria de Clavijo fuera por intervención del apóstol. Con posterioridad a la obra de Ferreras se hicieron nuevos intentos como el del padre Juan Manuel de Miñana, aparecida en 1733 o el del franciscano Nicolás Jesús de Belando y su Historia civil de España en dos tomos. A mediados del siglo xviII la Real Academia de la Historia planteó un nuevo proyecto de Historia de España, pero ya también se planteó cómo enseñarla en las escuelas por lo que hubo diversas propuestas para confeccionar manuales y el

Van añadidas a la postre unas tablas, que contienen el numero de los pontifices y emperadores romanos y origen y numero de los reyes de España y Francia, Impressa en Barcelona por Claude Bornat al Aguila fuerte. Año de 1562.

34. La obra de Lucio Marineo Sículo más editada en el siglo xvi fue De rebus Hispaniae memoriabilius, libri XXV [De las cosas memorables de España]. Hay ediciones de Alcalá, Manuel de Eguía, 1530 [edición moderna, Madrid, La Hoja del Monte, 2004].

35. Valera, D. de: Crónica de España. Sevilla, Alonso del Puerto, 1482, muy editado en el siglo xvi. Hay una edición zaragozana muy interesante, VAlERA, D. de: La cronica de España. Çaragoça, Jorge Cocci, 1513

36. Mariana, J. de: Historia General de España compuesta primero en latín, después vuelta en castellano por... Toledo, Pedro Rodríguez, 1601.

37. García Hernán, E.: «Construcción de las historias de España en los siglos xvir y XVIII», en GARCía CÁrCel, R. (coord.): La construcción..., op. cit., pp. 127-194, p. 143. 
primero que vio la luz fue una traducción al español de un Abrégé de l'Histoire de'Espagne del padre Claude Buffier (1661-1737) editado en París en 1704 y cuya versión española apareció en Madrid en 1734.

Hay otro tipo de literatura en la que los santos ocupan el primer plano de la narración y no es otra que la que acoge sus propias biografías, las Vitae o Flos, cuyos orígenes se remontan a las Actas martiriales y a la Leyenda Dorada de Jacobo della Voragine.

En la Contrarreforma se produjo una feliz coincidencia entre la necesidad pública de conocimiento de esos santos que había que tomar como modelo y que les servían de intermediarios con la providencia con la promoción que desde distintos ámbitos de la Iglesia debían de hacer para fortalecer órdenes religiosas, cabildos o territorios. Las órdenes religiosas fueron las más interesadas en promocionar a sus miembros ${ }^{38}$. Estamos ante una sociedad que busca en las vidas edificantes, en los santos, modelos a seguir ${ }^{39}$ y para ello las conductas religiosas, correctas, de ejemplaridad con caracteres sobrenaturales, de elección divina,

38. Bertelli, S.: «Santos contra santos», en Rebeldes, libertinos y ortodoxos en el Barroco. Barcelona, 1984, pp. 89-110; EgIDO, T.: «Hagiografía y estereotipos de santidad contrarreformista (La manipulación de san Juan de la Cruz)», Cuadernos de Historia Moderna, 25, 2000, pp. 61-86; GoNZÁLEz Lopo, D.: «Los nuevos modos de la hagiografía contrarreformista», Memoria Ecclesiae, 24, 2004, pp. 609-632; Quiles, F.: «La invención de la forma y la concreción del gesto. La hagiografía creada para la Sevilla barroca», en CARlos VArona, M. ${ }^{a}$ C. de, Civil, P., Pereda, F. y Vincent-Cassy, C. (coords.): La imagen religiosa en la Monarquía hispánica. Usos y espacios. Madrid, 2008, pp. 135-149; Bejarano, C.: «Santas medievales a los ojos barrocos», Tiempos Modernos, revista electrónica de Historia Moderna, 25, 2012; CARo BAROJA, J.: Formas complejas de la vida religiosa: religión, sociedad y carácter de la España de los siglos XVI y XVII. Madrid, 1978, pp. 77-106.

39. Arellano, I. y ViTse, M. (coords.): Modelos de vida en la España del Siglo de Oro. Tomo II. El sabio y el santo. Madrid, 2007, pp. 275-502; MuÑOz, F.: «La construcción de una vida edificante. Fray Ignacio de Santibáñez, arzobispo de Manila en 1598», en SERrano, E. (ed.): De la tierra al cielo. Zaragoza, 2013, pp. 117-133; id.: «Un catálogo de santidad. La segunda parte de la Crónica de la provincia franciscana de Burgos», en Atienza, Á. (ed.): Iglesia Memorable. Crónicas, historias, escritos... a mayor gloria. Madrid, 2012, pp. 323-341; GonzÁLEz Lopo, D. L.: «San Rosendo: de santo admirable a santo imitable. Un análisis comparativo de hagiografía medieval y barroca», Rudesindus, 1, 2007, pp. 17-44. EGIDO, T.: «Hagiografía y estereotipos de santidad..., op. cit., pp. 61-86; Álvarez Santaló, L. C.: «La escenografía del milagro hagiográfico y la construcción del imaginario colectivo», en RoDRÍGUEz BECERRA, S. (coord.): Religión y Cultura. Sevilla, 1999, vol. 2, pp. 141-172; CAFfiero, M.: La fabrique d'un saint à l'époque des Lumières. París, 2006; Dossier: Le temps des saints. Hagiographie au siécle d'or, en Mélanges de la Casa de Velázquez, 33-2, 2003; Delpech, F.: L’imaginaire du territorire en Espagne et Portugal (Xvie-Xvilie siècles). Madrid, 2008; Carlos Varona, M. ${ }^{a}$ C. de, Civil, P., Pereda, F. y Vincent-Cassy, C. (coords.): La imagen religiosa en la Monarquía hispánica..., op. cit. Dossier: Fábrica de Santos: España, siglos xvi y xvII, en Revista de Historia Jerónimo Zurita, 85, 2010. 
con portentos sacralizados asumidos naturalmente responden a esa demanda. Importante va a ser la proliferación de esas vidas de santos que continúan los Flos medievales ${ }^{40}$. La hagiografía conoció su época de esplendor con la iniciativa del jesuita Jean Bolland (1596-1665) y su continuación con la Sociedad de Bolandistas, de recoger sistemáticamente, de forma científica, de todos los martirologios, de recopilaciones antiguas de biografías o hechos de hombres santos y de las encuestas de los procesos, los datos con los que conformar relatos biográficos verdaderos, y de publicar críticamente las vidas de los santos, en Acta Sanctorum, señalando aquellos pasajes que pudieran ser o parecer poco históricos, fabulosos o incluso legendarios ${ }^{41}$.

Sobre la hagiografía se han escrito páginas muy esclarecedoras desde la historia de la literatura. José Aragüés mostró los caminos seguidos por los legendarios castellanos desde los latinos, dividiendo en los medievales y renacentistas con la Leyenda Dorada ca.1260 con sus diferentes compilaciones que llegaron a los Flos renacentistas y a la Leyenda de los santos a través del Flos y sus Etimologías. Por otro lado los legendarios postridentinos con los Vitae Sanctorum de Lipomano de 1575 y sus derivaciones en el Flos de Villegas (desde 1578 hasta 1794) y los Flos de Ribadeneyra (desde 1599 hasta 1791). Este stemma también lo corrobora Fernando Baños, la otra gran referencia hispana. Aragüés y Baños analizan la trayectoria editorial de ambas tradiciones, que tienen el mismo origen latino ${ }^{42}$.

Pero todos estos Flos y Vitae se refieren, mayoritariamente, a santos antiguos, anteriores a la eclosión de ese fortín de santidad en que se convirtió España. Y aquí la escritura de las vidas de estas personas, algunas ya santas, otras llamadas a la santidad, es muy importante. Muchas de estas vidas son encargos previos al inicio del proceso de beatificación o canonización. Se trata de justificar, a través de los ejemplos de estas vidas esforzadas, la reclamación de santidad; de persuadir,

40. Villegas, A. de: Flos sanctorum. Zaragoza, Simon de Portonariis, 1585; Rivadeneyra, P. de: Segunda parte del Flos sanctorum. Madrid, Luis Sánchez, 1601; también en Obras escogidas, Biblioteca de Autores Españoles LX (Libro de la vida de santos); Español, F. y Fité, F. (eds.): Hagiografía peninsular en els segles medievals. Lleida, 2008.

41. Delehaye, H.: L'oeuvre des Bollandistes à travers trois siécles (1615-1915). Bruselas, 1959, 2. ${ }^{a}$ ed.; Godding, R., Joassant, B., Leques, X., VRiendt, F. de y Straeten, J. van der: Bollandistes, saints et legends. Quatre siécles de recherche hagiographique. Bruselas, 2007.

42. AragüÉs, J.: «Para el estudio del 'Flos sanctorum renacentista'(I), la conformación de un género», en VITSE, M. (ed.): Homenaje a Henri Guerreiro..., op. cit., pp. 97-147; Carvajal, H. y González-SARASA, S.: «Los Flos sanctorum: la impronta de la tradición manuscrita en la evolución de un producto editorial», en Fernández Rodríguez, N. y Fernández Ferreiro, M. (coord.): Literatura medieval y renacentista en España: lineas y pautas. Salamanca, 2012, pp. 433-442; BAÑos, F.: «El conocimiento de la hagiografía medieval castellana. Estado de la cuestión», en ViTse, M. (ed.): Homenaje a Henri Guerreiro..., op. cit., pp. 65-96. 
con las bondades de una vida honesta, a la jerarquía eclesiástica, de la inexistencia de inconvenientes; de demostrar, con los milagros, que el camino a los altares se encuentra expedito. Estos discursos, vidas de santos, informes y procesos de canonización tendrán un encaje social y un análisis territorial de los promotores.

\section{RELIQUIAS Y MÁRTIRES, OBISPOS Y EREMITAS}

El culto a las reliquias y el deseo de apropiarse de fragmentos de cuerpos santos durante la Edad Moderna produjo una proliferación de falsificaciones que no pudieron ser frenadas por los decretos de Trento en los que se indicaba que debían ser los obispos y finalmente la santa Sede quienes debían certificar las mismas y determinar los milagros. La necesidad de reliquias vino dada entre otros motivos por la necesidad de dotar a las iglesias de elementos que las prestigiaran, que hicieran atractivo el enterramiento en ellas y que los miembros de las clases privilegiadas encontraran los medios para santificar aquellos lugares en donde querían ser enterrados. Producida la inventio de las reliquias y afianzado el culto al santo, la expansión de la devoción provocaba la afluencia de fieles y con ello las remesas de donaciones y ofrendas.

Los intereses de las ciudades españolas por la posesión de reliquias de santos se manifestó de manera cruda en los interminables pleitos que las enfrentaron y en la defensa que a través de memoriales y escritos hicieron de su posesión. Hubo también muchas peticiones de fragmentos de cuerpos santos (hablamos ahora solo de los santos que fueron o ejercieron de patronos de las ciudades) para satisfacer esos anhelos de compartir los beneficios piadosos y de intercesión que se le atribuían a los santos a través de las reliquias. Y no todas las reliquias se consiguieron de manera clara o con la anuencia de propietario y peticionario. Sancho Dávila y Toledo (1546-1625) publicó en 1611 un tratado sobre la veneración de las reliquias de acuerdo a los cánones conciliares de Trento ${ }^{43}$. Este teólogo fue obispo de Murcia, Jaén, Segorbe y Plasencia y era hijo primogénito del marqués de Velada. Hizo trasladar a Murcia, donde era obispo, las reliquias de san Fulgencio y santa Florentina de la villa de Berzocana de san Fulgencio en el obispado de Plasencia, con la oposición de los habitantes de la villa, aunque con la autorización de Felipe $\mathrm{II}^{44}$. Esta relación íntima entre el coleccionismo de reliquias -Sancho Dávila lo fue-, la labor pastoral y la difusión de santos protectores en villas y ciudades a

43. DÁvila, S.: De la veneración que se debe a los cuerpos de los Sanctos y a sus reliquias... Madrid, Luis Sánchez, 1611.

44. Bouza, J. L.: Religiosidad contrarreformista y cultura simbólica del Barroco. Madrid, 1990, pp. 71-79. 
través de escritos y otros medios de divulgación fue habitual en la Edad Moderna, como lo fue también el despojo en los momentos de la presentación del cadáver del tenido como santo (mordiscos para arrancarles dedos, paños empapados en sangre, vestiduras y joyas...), el robo de reliquias y el tráfico internacional y la falsificación de muchas de ellas.

En ocasiones es la devoción de la aristocracia la que lleva reliquias a los conventos o iglesias de sus lugares de origen; ese parece ser el caso de las reliquias de san Francisco Solano (1549-1610) y santa Rosa de Lima (1586-1617) conservados en La Puebla de Castro en la actual provincia de Huesca. Llama la atención el hecho de que sean ambos dos santos americanos, aunque en los dos casos sus tumbas se hallan en Lima. Es muy probable que la quinta marquesa de La Puebla de Castro, Teresa del Milagro Moncada Benavides, casada en 1722 con el undécimo duque de Medinaceli, Antonio Fernández de Córdoba y Figueroa, señor de Montilla, lugar de nacimiento de san Francisco Solano, o su hijo, que restauró la iglesia dedicada al santo en Montilla, donaran las reliquias. En el inventario de 1774 de los Bienes de la iglesia parroquial de La Puebla de Castro se citan ambas reliquias en sendos relicarios. De ser este el camino, su llegada se produciría entre la beatificación del franciscano en 1726 y la redacción de dicho inventario ${ }^{45}$.

$\mathrm{La}$ «invención» de los santos debe entenderse como el descubrimiento de las tumbas de los mártires sobre una tradición inveterada «milagrosa», y con manifestaciones sobrenaturales, hierofanías u otros prodigios que señalaban la tumba, que se ve acompañada de efectos bienhechores para la comunidad que participa de la presencia material de sus huesos y el influjo sobrenatural de sus efectos miríficos ${ }^{46}$. Muy habituales fueron las intervenciones sobrenaturales que señalaban el enterramiento de cuerpos santos, casi siempre en un sueño o en la vigilia; y casi siempre a obispos o eclesiásticos de importancia en los límites de sus diócesis o en territorio bajo su jurisdicción. A san Ambrosio le fue revelado el paradero de san Gervasio y san Protasio en el $386^{47}$, al obispo de Bolonia los santos Vidal y Agrícola de la misma ciudad y aparecieron en el siglo v san Esteban, Ababuc, Miqueas, Zacarías, Bernabé, Eutropio, Benigno o Ferreol ${ }^{48}$. En el siglo v quedaban identificados por su reputación entre la gente al sufrir el martirio, por sus historias y leyendas de sus vidas como ejemplo de virtudes heroicas y sus

45. Arco, R. del: Catálogo monumental de España. Huesca. Madrid, 1942, p. 293.

46. Memoria Ecclesiae, 21, 2002. Monográfico sobre reliquias; Bozóky, E. y Helvétıus, A. M. (eds.): Les reliques. Objets, cultes, symboles. Turnhout, 1999.

47. San Agustín: Confesiones IX, 7, Madrid, BAC, 1963, pp. 349-351.

48. BouzA, J. L.: Religiosidad contrarreformista..., op. cit., p. 26. 
obras milagrosas, creciendo su culto de modo exponencial entre los siglos vi y $\mathrm{x}$ y detectándose abusos alentados por la posesión de reliquias.

Estos fragmentos de santidad serán utilizados como marcadores de territorio, como propone Bozóky ${ }^{49}$, e incluso llegarán a convertirse en núcleos sobre los que emergerán territorios poderosos, instituciones potentes y con gran poder, y junto a ello familias que lograrán una gran influencia. Tampoco debemos olvidar que las reliquias tendrán un papel muy destacado en la sacralización y la legitimación del poder real y de las dinastías reales en occidente y desde la Edad Media ${ }^{50}$. También el siglo Xvi conocerá la crítica humanista y religiosa de las reliquias. Había también algunos lugares del mundo católico que seguían ofreciendo reliquias de los santos cuyos cuerpos custodiaban. El caso de Santa Engracia en Zaragoza ${ }^{51}$, un foco de religiosidad y devoción grandes y uno de los depósitos de reliquias más significativos de España, escenifica todo el interés que una ciudad, sus jerarquías y gobernantes, tienen por manipular, manejar el reparto y el acceso o mantener su culto bajo su control.

La propiedad o custodia de reliquias será un aspecto importante por el que las jerarquías eclesiásticas y civiles pugnarán incluso de manera desleal; recuérdese el dedo de san Ildefonso ${ }^{52}$ o el desmembramiento de no pocos santos, empezando por Teresa de Jesús ${ }^{53}$. La legitimidad conseguida con la veneración de los cuerpos santos, la cohesión y aglutinación en torno a su memoria y culto ${ }^{54}$ y el providencia-

49. Bоzóky, E.: La politique des reliques de Constantin à Saint Louis. París, Beauchesne, 2006; Bouza, J. L.: Religiosidad contrarreformista..., op. cit.

50. Hermann-Mascard, N.: Les reliques des saints. Formation coutoumière d'un droit. París, 1975; Reliquias políticas I. Cuerpos santos de Antiguo Régimen, Coloquio en la Casa de Velázquez, 19-20 de marzo de 2015; Geary, P. J.: Furta sacra. Thefts of Relics in the Central Middle Ages. Princenton, 1978.

51. Serrano Martín, E.: «Huesos de santo. Santa Engracia y la entrega de reliquias en las entradas reales zaragozanas», en PeÑa, M. (ed.): La vida cotidiana en el mundo hispánico (Siglos XVI-XVIII). Madrid, 2012, pp. 407-24.

52. TAusiet, M.: El dedo robado. Reliquias imaginarias en la España moderna. Madrid, 2013.

53. Madre De Dios, E. de la y Steggink, O.: Tiempo y vida de santa Teresa. Madrid; Pérez, J.:Teresa de Ávila y la España de su tiempo. Madrid, 2007.

54. Ramallo, G.: «Reactivación del culto a las reliquias en el barroco. La catedral de Oviedo y su Cámara Santa en 1639, Liño, 11, pp. 77-91; González Lopo, D. L.: «El papel de las reliquias en las prácticas religiosas de los siglos Xvi y xviII», en Álvarez Santaló, L. C. y Cremades Griñán, C. (eds.): Mentalidad e ideología en el Antiguo Régimen. Actas de las II Reunión Científica de la Asociación Española de Historia Moderna. Murcia, Vol. II, 1993, pp. 247-260; Cofiño, I.: «La devoción a los santos y sus reliquias en la iglesia postridentina: el traslado de la reliquia de san Julián a Burgos», Studia Historica: Historia Moderna, 25, 2003, pp. 351-378. 
lismo que rodeaba toda actuación social, hicieron de su posesión un bien preciado que había que proteger; había que «privatizar» o «personalizar» el tangible apoyo sobrenatural en la presencia taumatúrgica de las reliquias. Pero también forman parte de una religiosidad popular que nos hace visibles devociones, mecenazgo, coleccionismo, transgresiones ${ }^{55}$.

A comienzos del siglo xvir y en un contexto de reivindicación martirial muy importante en España y en todo el orbe católico con las persecuciones de misioneros en los países extremos, con la aceptación del martirio como incontrovertible fuente de santidad para las autoridades romanas y con el excesivo uso de las reliquias, incluidas las de los santos catacumbales, se produjo un rebrote de la valoración de las personas santas vinculadas a la patria de cada cual, casi siempre con intención por parte de las oligarquías urbanas. Hay una inflación de hagiografías, estudios, iconografía que van a ser usados para dar a conocer la especial relación y el interés del santo por mostrarse propicio hacia su tierra: santos locales, con filiación patronal ${ }^{56}$, cuyo origen real o inventado llenó miles de páginas de erudición y polémica. De tal forma se creará una auténtica sacralidad territorial, una protección del espacio sobre la base de la especial predilección del santo. Resulta evidente con los ejemplos de Justo y Pastor en Alcalá de Henares ${ }^{57}$, Justa y Rufina en Sevilla ${ }^{58}$, Julián en Cuenca ${ }^{59}$ o Lorenzo en Huesca ${ }^{60}$.

55. Postigo Vidal, J.: La vida fragmentada. Experiencias y tensiones cotidianas en Zaragoza (Siglos XVII y XVIII). Zaragoza, 2015, pp. 299-338.

56. Gómez Zorraquino, J. I.: «Los santos patronos y la identidad de las comunidades locales en la España...», op. cit.

57. Canalda, J. C.: Los santos Justo y Pastor en España. Alcalá de Henares, Asociación Hijos y Amigos de Alcalá, 1998; Memorial a Su Santidad... suplicando se sirva ampliar el rezo de los santos Martyres Justo y Pastor, para todo el orbe christiano [sl.,sI], pero posterior a 1614; San Juan, Fray I. de: Oración evangélica de San Justo y Pastor, patronos de Alcalá de Henares $y$ de la insigne parroquial de Granada. Granada, 1687; Morales, A. de: La vida, el martirio, la invención, las grandezas... santos Justo y Pastor... en Alcalá de Henares... Alcalá, 1568; Andrés De Uztarroz, J. F.: Monumento de los santos martyres Justo y Pastor, en la ciudad de Huesca... Huesca, Juan Nogués, 1644 [Edición facsímil con introducción de GiL, Fermín y Chauchadis, Claude, Huesca, Instituto de Estudios Altoaragoneses, 2005].

58. Vincent-Cassy, C.: «La propagande hagiographique des villes espagnoles au Xvire siècle. Le cas de Sainte Juste et de Sainte Rufine, patrones de Séville», Melanges de la Casa de Velázquez, 33-2, 2003, pp. 97-130.

59. Jiménez Monteserín, M.: Vere pater pauperum. El culto de San Julián en Cuenca. Cuenca, 1999.

60. Gómez Zorraquino, J. I.: Los santos Lorenzo y Orencio se ponen al servicio de las «tradiciones». Siglo XviI. Huesca, 2007; Andrés De Uztarroz, J. F.: Defensa de la patria del invencible mártir San Laurencio... Zaragoza, Hospital Real y General de Nuestra Señora de Gracia, 1638; Dormer, D. J.: San Laurencio defendido siempre en la siempre vencedora y nobilisima ciudad de Huesca... Zaragoza, Francisco Revilla, 1698. 
La referencia martirial más significativa de la Hispania cristiana es sin duda la cripta de santa Engracia en Zaragoza ${ }^{61}$. El más antiguo testimonio sobre los primeros cristianos zaragozanos e incluso hispanos data de los años 254-255 y es la epístola 67 de Cipriano de Cartago, luego canonizado, en la que alude a un «Felix de Caesaraugusta, fidei cultor ac defensor veritatis...». De esta escueta referencia se puede colegir que en 254-255 existía una comunidad cristiana en Zaragoza a la que pertenecía el citado Félix.

Zaragoza tenía un templum con las reliquias de Engracia y los 18 mártires cantados por Prudencio en su Peristephanon (De las Coronas), compuesto a comienzos del siglo v y del que hizo una traducción Luis Díez de Aux en $1619^{62}$. Son estos Carmina la más antigua fuente para conocer las persecuciones contra los cristianos en Caesarangusta, muy probablemente caídos en la persecución de Valeriano (entre 253-260). Los llamados Innumerables en el Peristephanon fueron dieciocho mártires cuyos huesos y cenizas se guardaban en un sepulcro común. Los restos del cuerpo de santa Engracia se guardaban en otro sepulcro, según tradición lejana a los hechos. Prudencio relata el martirio de los 18 compañeros de esta virgen, y para muchos princesa lusitana, que fueron azotados y decapitados. A Engracia le ataron a unos caballos y le arrastraron por la ciudad, le flagelaron al día siguiente con cuchillas y garfios, le arrancaron parte del hígado, le amputaron el pecho izquierdo dejando a la vista su corazón y parece que, en tradición posterior al siglo xII, añadieron la tortura y muerte con un clavo en la cabeza. La leyenda de la princesa lusitana que sufre martirio durante las persecuciones de Daciano tiene en Prudencio su principal exégeta, en el siglo vir se construyó toda la leyenda, quizás en el siglo XIV con el descubrimiento de las reliquias se añadió el clavo y Carrillo, Murillo y Martón y los escritores de los siglos XviI y xviII quisieron dar verosimilitud al relato legendario fijando las fechas del tormento y muerte y su conmemoración el día 16 de abril. Así se representa a la santa, con la palma del martirio y un clavo en la frente. Carrillo y Murillo, en sendas publicaciones, pretenden revitalizar el culto y afianzar la devoción ${ }^{63}$.

61. Las páginas que siguen sobre santa Engracia están tomadas de mi estudio sobre el Pilar, vid. Serrano Martín, E.: El Pilar, la historia y la tradición. La obra erudita de Luis Diez de Aux (1562-ca. 1630). Zaragoza, 2014, pp. 23 y ss.; García Herrero, M. ${ }^{a}$ C. y Criado, J.: «Orosia y Engracia, princesas santas de la montaña y del llano», en García Herrero, M. ${ }^{a}$ C.: Artesanas de vida. Zaragoza, 2009, pp. 261-312.

62. Prudencio: Obras, introducción, traducción y notas de Luis Rivero García. Madrid, 1997; Díez De Aux, L.: Traducción de los bimnos que bizo Aurelio Prudencio, a los ilustrísimos martyres san Laurencio, san Vicente, santa Engracia, san Lupercio y los demás innumerables que padecieron en la Imperial Ciudad de Çaragoça. Zaragoza, Luis de Lanaja y Quartanet, 1619.

63. Sobre la patria de la mártir, Carrillo piensa que es de Zaragoza, mientras que Murillo sostiene el origen portugués, vid. CARRILlo, M.: Historia del glorioso san Valero obispo de la ciudad 
Para la revitalización del culto se tendrán en cuenta la imagen martirial de Engracia y sus compañeros, con toda la potencia simbólica de los episodios que se suceden que tienen su paralelismo en la pasión de Jesús, incluida la columna donde fue flagelada y que es, según la leyenda, parte del palacio de Daciano y posterior elemento de la cripta, que hubo de protegerse con hierro porque arrancaban fragmentos de la misma. Al mismo tiempo la construcción del conjunto de los mártires, de los 18 transformados en Innumerables, como una militia christi compuesta por tropa cuantiosa a cuya cabeza se encontraba Engracia, es otra vuelta en el relato hagiográfico. Pero sin ninguna duda lo que contribuyó sobremanera a su verdadera importancia en el conjunto devocional zaragozano y en el espacio público concejil fue la puesta bajo protección de los monarcas del conjunto monástico con la erección de un nuevo cenobio de la orden jerónima. Y añadido a ello el control ciudadano de la cripta y de las reliquias. A lo largo de la Edad Moderna se puede comprobar que el culto a Engracia y sus compañeros no dejó de crecer y entre las elites ciudadanas la basílica extramuros de la ciudad es un referente de prestigio y poder, lo que llevará a que grandes personajes de familias ilustres y miembros destacados de cierta elite intelectual y política fueran enterrados en los claustros del monasterio, sepulcros de los que solo queda la memoria, ya que fueron destruidos en su totalidad durante la guerra de la Independencia. Entre las tumbas estaba la del propio canciller Le Sauvage, muerto el 7 de junio de 1518 mientras acompañaba a Carlos I en las Cortes de Zaragoza y cuyo sepulcro labró Alonso Berruguete en la capilla de san Juan Bautista sufragado por el futuro emperador. La capilla de san Jerónimo era propiedad del vicecanciller de Aragón Antonio Agustín, cuyo túmulo funerario fue obra de Gil Morlanes ${ }^{64}$. También fueron inhumados los cronistas de Aragón Jerónimo Zurita y Jerónimo Blancas.

En momentos tan especiales para la ciudad como las visitas regias, el concejo dispuso de representaciones teatrales en los que mostrar el martirio de Engracia. Aunque se montaron representaciones en carros que recorrían la ciudad, la más significativa tuvo lugar en 1533 en una visita a la ciudad de la Emperatriz Isabel enfrente de la puerta Cinegia. Encargada a Fernando Basurto una pieza sobre el martirio de Engracia, el autor destacó la procedencia lusitana de Isabel y Engracia

de Çaragoça. Con los martyrios de san Vicente, santa Engracia, san Lamberto y los Innumerables martyres, naturales, patrones y protectores de la ciudad de Çaragoça. Con un catálogo de todos los prelados, obispos, arzobispos y abades de Aragón. Zaragoça, Juan de Lanaja, 1615; Murillo, D.: Fundación milagrosa de la Capilla Angelica y Apostolica de la madre de Dios del Pilar y Excellencias de la imperial ciudad de Çaragoça... Barcelona, Sebastián Matevad, 1616, p. 266.

64. Morte, C.: «El patrocinio artístico de las clases privilegiadas: prestigio y devoción durante el Renacimiento en Aragón», en IBÁÑ̃z, J. (coord. y ed.): Del mecenazgo a las nuevas formas de promoción artística. Zaragoza, 2017, pp. 45-102, pp. 71-72. 
y su sangre real: «que por ser su traje / y su persona real / veréis ser de Portugal / de vuestro mismo linaje» ${ }^{65}$.

También hubo muchos momentos en que los ilustres visitantes se acercaron piadosamente al monasterio y solicitaron alguna reliquia, siempre controladas en un armario o en el pozo por el concejo de la ciudad, celoso guardián que negó en no pocas ocasiones regalo tan significativo. Esta entrega de reliquias suponía en la práctica un poder muy grande, porque los jurados tenían la llave de una poderosa protección y el control de una parte sustancial de la vida religiosa y devocional zaragozanas ${ }^{66}$. Una parte la compartían en las procesiones en las que las reliquias de los santos que se encontraban en la cripta martirial se juntaban con los santos ciudadanos de La Seo y en peana eran paseados y eran vistos por el conjunto de la población zaragozana, que de este modo sentía su fuerza taumatúrgica. Para que la leyenda llegase a un sector más grande de población fue traducido el Peristephanon de Prudencio por Luis Díez de Aux en 1619, como se ha señalado, y muchas de las historias publicadas en los siglos XVII y XVIII recogieron el martirio de Engracia y sus compañeros, significativamente Martín Carrillo, Diego Murillo o el padre Benito Martón ${ }^{67}$. Como ocurría con todos los monasterios jerónimos, los monarcas disponían en el cenobio de unas habitaciones que los monarcas de la Casa de Austria utilizaron en diversas visitas. En 1646 murió en la ciudad el príncipe Baltasar Carlos y su padre se retiró al monasterio de santa Engracia durante un buen número de días ${ }^{68}$.

Las reliquias de Engracia y los Innumerables se conservaron en una basílica martirial reconsagrada después del Concilio de Zaragoza del año 592 y dedicada a los Innumerables mártires en el 619 por el obispo Máximo. Los arqueólogos afirman que dicha basílica se hallaba sobre la necrópolis cristiana datada en el siglo IV $^{69}$. Incluso desde el siglo vir se podían sacar huesos por un orifico

65. Río, A. del: Teatro y entrada triunfal en la Zaragoza del Renacimiento (Estudio de la «Representación del Martirio de santa Engracia» de Fernando Basurto en su marco festivo). Zaragoza, 1988.

66. Serrano Martín, E.: «Huesos de santo. Santa Engracia y la entrega de reliquias...», op. cit.

67. Martón, Fray B.: Origen y antigüedades de el subterráneo y celebérrimo santuario de Santa María de las Santas Masas, oy Real Monasterio de Santa Engracia de Zaragoza de la Orden de nuestro Padre san Jerónimo. Zaragoza, Juan Malo, 1737. (Hay edición facsimilar con introducción de Ángel San Vicente, Zaragoza, Gobierno de Aragón, 1991).

68. Andrés De Uztarroz, J. F.: Obelisco histórico y honorario, que la imperial ciudad de Zaragoza erigio a la inmortal memoria del Serenissimo Señor don Balthasar Carlos de Austria, principe de las Españas... Zaragoza, Hospital de Nuestra Señora de Gracia, 1646.

69. Escribano Paño, M. V.: Los primeros testimonios cristianos en Aragón, en Aragón antiguo. Fuentes para su estudio. Zaragoza, 2013, pp. 678-91, pp. 687 y ss.; EsCRIBAno PAÑo, M. V. y FATÁs, G.: La Antigüedad tardía (287-714). Zaragoza, 2001, p. 29. 
practicado en un sarcófago llamado Receptio animae labrado alrededor del 330. Durante la ocupación musulmana se ocultaron las reliquias y muy posteriormente, en 1320, fueron halladas con inscripciones identificativas de Lupercio y Engracia unas arquetas ${ }^{70}$. La noticia del hallazgo la sitúa el cronista Jerónimo Zurita en 1389, ya con los nombres de ambos mártires ${ }^{71}$. Por tanto, para los zaragozanos este era un foco de devoción significativo en la ciudad y en el que se radicaron varias cofradías: la de santa Engracia, la de los santos Mártires, san Martín, de la crucifixión del Señor y santa María y la de santa María de la Anunciación ${ }^{72}$. Tampoco debe olvidarse que es patrona de la ciudad desde el 16 de abril de 1480 y que su pozo de reliquias tendrá una gran importancia para satisfacer el ansia de «huesos de santo» de la sociedad española y sus dirigentes durante toda la Edad Moderna, movidos por el espíritu contrarreformista que, con la veneración de estos cuerpos santos, o partes de ellos, les diferenciaba de los protestantismos ${ }^{73}$.

La iglesia de Santa Engracia o de las Santas Masas era, a comienzos del siglo xv, una de las más importantes y el mecenazgo ejercido por los monarcas y otras instancias eclesiásticas, intenso. Incluso el Papa Benedicto XIII (1394-1423) regaló un busto relicario para contener el cráneo de Engracia ${ }^{74}$, pieza destruida en 1810, aunque se conserva el cráneo en otro relicario de plata. La difusión de este modelo también nos indica la importancia que ofrecía, no solo la joya argéntea, sino también la referencia martirial y de santidad que albergaba. En 1492 se fundó el monasterio por parte de Fernando II en cumplimiento de la voluntad

70. Martínez, J.: Jaime II de Aragón: su vida familiar. Barcelona, 1948, t. II, pp. 235-236.

71. Cabanes, M. D.: «Inscripciones medievales encontradas en el sepulcro de Santa Engracia y San Lupercio. Paleografía y reliquias», en Santa Engracia. Nuevas aportaciones para la bistoria del monasterio y basílica. Zaragoza, 2002, pp. 69-82; Mostalac, A.: «Novedades sobre el sarcófago de la Receptio animae, tras su restauración y extracción del arcosolio del muro de la epístola, de la basílica menor de Santa Engracia», en Santa Engracia. Nuevas aportaciones, op. cit., pp. 42-58. Sobre las fechas vid., CRIADO, J.: «La fábrica del monasterio jerónimo de Santa Engracia, 1492-1517», Artigrama, 13, 1998, pp. 253-76, en pp. 253-254.

72. CAmpo, A. del: «Aproximación a un mapa devocional de Zaragoza en el siglo XIV», en Turiaso, XVI, pp. 87-143, en p. 140.

73. Serrano Martín, E.: «Huesos de santo. Santa Engracia y la entrega de reliquias...», op. cit.

74. Criado Mainar, J.: «Los bustos relicarios femeninos en Aragón. 1406-1567», en García Herrero, M. C. y Pérez, C.: Las mujeres en la Edad Media: aspectos políticos, socioeconómicos $y$ culturales. Zaragoza, 2014, pp. 341-368; Criado Mainar, J. y Escribano, J. C.: «El busto relicario de san Valero de la Seo de Zaragoza. Noticia de su reforma por Francisco Agüero (ca. 1448-1452)», Boletín del Museo e Instituto Camón Aznar, LIX-LX, Zaragoza, 1995, pp. 119-150. 
testamentaria de su padre y lo dotó con unas rentas de varios obispados vacantes, además de torres, terrazgos, granjas y censales ${ }^{75}$.

El caso de san Lorenzo, bien estudiado por José Ignacio Gómez Zorraquino, es paradigmático de cómo las elites ciudadanas reivindicaron la patria del santo con escritos, a veces no tanto por iniciativa propia como respuesta a las reivindicaciones foráneas. Y aunque autores como Dormer tuvieran ciertas reticencias a tomar como autoridad los cronicones de Dextro, sin embargo defendió sin ambages la patria oscense de Lorenzo. Al margen de la historicidad y de los debates que ha habido sobre ello, en el asunto de los santos antiguos y en el de los mártires más particularmente se viene discutiendo sobre la patria (el lugar de nacimiento) y el lugar de martirio o lugar de nacimiento a la gloria. De este modo Roma esgrimió su candidatura, pero solo en contadas referencias. En 1662 el concejo de Huesca quiso tomar las riendas contra las reivindicaciones cordobesas al enterarse de que Francisco Carrillo planeaba la publicación de un libro en el que esgrimía la patria cordobesa y el consistorio acordó que debía procurar que no se editase ningún texto en el que figurase otro lugar de nacimiento que fuera Huesca porque era «ageno a la verdad» ${ }^{76}$. Del mismo modo se debieron ocupar de la obra póstuma de Juan Bautista Ballester, Piedra de toque que reivindicaba Valencia como cuna de san Lorenzo ${ }^{77}$. Las elites oscenses, bien asentadas en el concejo de la ciudad, con representación de pequeños señores jurisdiccionales, baja nobleza, notarios y juristas, elevaron protestas ante las autoridades regnícolas y solicitaron protección a las instituciones forales y a la Monarquía por las injerencias de valencianos y cordobeses. Con la publicación de diversos libros de una reconocida intelectualidad aragonesa -Dormer, Lastanosa, Andrés de Uztarroz, Aynsa, Aguas, Carreras...-, las fiestas por los traslados de reliquias o por la conmemoración del martirio y la construcción del templo de san Lorenzo

75. Santa Engracia. Nuevas aportaciones..., op. cit. En 1993 la revista «Aragonia Sacra» dedicó un número monográfico (VII-VIII) a la historia del monasterio. CRIAdo MaInAR, J.: «La fábrica del monasterio jerónimo...», op. cit.; Ansón, A.: «La iglesia alta del Real Monasterio de Santa Engracia de Zaragoza: aproximación a un monumento desaparecido», Seminario de Arte Aragonés, XXIX-XXX, 1979, pp. 5-26; IвÁÑEZ, J.: La portada escultórica de Santa Engracia. Aproximación histórica y breve estudio artístico e iconográfico. Zaragoza, 2004; Cía Blasco, J.: «Precedentes y orígenes del monasterio jerónimo de Santa Engracia de Zaragoza», Revista de Historia Jerónimo Zurita, 76-77, 2001-2002, pp. 7-90.

76. Gómez Zorraquino, J. I.: Los santos Lorenzo y Orencio..., op. cit., p. 28.

77. Ibid. p. 29. También las páginas 61-66 del artículo citado de Gómez Zorraquino, J. I.: "Los santos patronos...», op. cit.; Ballester, J. B.: Piedra de toque de la verdad. Peso fiel de la razón, que examina el fundamento con que Valencia y Huesca contienden, sobre cual es la verdadera patria del invicto mártir san Lorenzo. Barcelona, Sebastián de Comellas, 1673. 
en Huesca (entre 1608 y 1703), debido al mecenazgo de miembros de esa elite ciudadana que de este modo sentían la protección del santo y sus favores, el culto y difusión quedó bien asentado.

Lorenzo y su hermano gemelo o mellizo Orencio eran hijos de san Orencio, obispo de Auch, y de santa Paciencia. La tradición indica que habían nacido en una casa cuyo solar ocupa hoy la basílica de san Lorenzo y que habían estudiado primero en Huesca y luego Teología en Zaragoza. Este relato sobre los padres, nacimiento y estudios se encuentra en casi todos los escritores, historiadores y cronistas. Lorenzo se fue a Roma, donde fue diácono de Sixto II y según el Martirologio Romano sufriría el conocido martirio de la parrilla en las persecuciones del emperador Valeriano entre el 252 y 258. Su madre murió al poco y los dos Orencios, padre e hijo, fueron al valle de Lavedan en Francia y el hijo, después de un tiempo de vida eremítica, fue elegido obispo de Auch. El padre Orencio volvió a Huesca, donde realizó diversos milagros haciendo llover abundantemente y murió al poco de su regreso y fue enterrado junto a su mujer en la pardina de Loreto. Los relatos aragoneses y franceses concuerdan en muchos aspectos. La traslación de las reliquias del obispo y hermano de san Lorenzo reviste mucho interés y se ha ocupado ampliamente Gómez Zorraquino ${ }^{78}$. En la llegada de las reliquias tiene un papel muy destacado el caballero zaragozano exiliado Manuel Donlope, gentilhombre de la cámara del rey francés Enrique IV, quien redimía de esta manera su participación y la de su familia en la rebelión aragonesa de 1591. Autorizado el traslado, el arzobispo de Auch pidió que el obispo de Huesca, el cabildo de la diócesis y la ciudad mostrasen con un escrito su devoción al santo, el lugar donde se iban a venerar las reliquias y su deseo expreso de contar con ellas. Al mismo tiempo solicitaba reliquias de los cuerpos de Orencio y Paciencia. Las fiestas fueron espectaculares y la ciudad y sus representantes participaron en procesiones, Te Deum y celebraciones caballerescas y la universidad organizó una Justa poética. Es toda una ciudad identificada con sus santos al que concedieron su patronazgo.

La ciudad de Huesca cuenta con un busto relicario, realizado posiblemente para acoger la reliquia de san Lorenzo traída desde Roma el 8 de agosto de 1578, solicitada al papa Gregorio XIII por don Juan Olivito, deán de la catedral de Huesca $^{79}$. También se conservaba un dedo en un relicario de plata donado por

78. Gómez Zorraquino, J. I.: Los santos Lorenzo y Orencio..., op. cit., p. 99-136

79. Ainsa, Diego: Fundación, excelencias, grandezas y cosas memorables de la antiquísima ciudad de Huesca. Huesca, Pedro Cabarte, 1619, p. 484, citado en Gómez Zorraquino, J. I.: Los santos Lorenzo y Orencio..., op. cit., p. 11. 
Jaime II en $1307^{80}$. Es por tanto un patronazgo sostenido por la posesión de reliquias $\mathrm{y}$ culto inmemorial y un patronazgo que no necesita los procesos informativos que vinculan los decretos de 1630.

En el caso de traslación de reliquias como acrecentamiento de devoción y afianzamiento de la jerarquía eclesiástica tenemos a san Julián, obispo de Cuenca, del que se trasladó una reliquia a Burgos, su ciudad natal ${ }^{81}$, en 1700. La difusión del culto a este obispo de Cuenca entre 1198 y 1208 hay que buscarla en el interés del cabildo catedralicio por dar prestigio y transformar el lugar en un centro de peregrinación y ampliar, como así se hizo, los límites de su devoción, llegando a ser un santo muy popular que traspasó las fronteras de la diócesis y de España. Como en muchos otros casos, el perfil de santidad se fue fraguando a lo largo de los años en los que se fue ahormando su vida con los consabidos milagros. No hay conmemoración litúrgica de su santidad hasta dos siglos después de muerto, en 1447 y no se hizo continuada hasta 1471. En 1518 se trasladó el sepulcro del obispo a la capilla mayor de la catedral y nuevamente movidos con la construcción del Transparente del altar mayor en 1760. En la Guerra civil su cuerpo fue destruido, salvándose solo unos fragmentos autentificados en $1944^{82}$. El cabildo conquense exhibió el cuerpo del obispo y se concedieron cuarenta días de indulgencias para todos los que visitasen su tumba. También organizaron una solemne procesión con su cuerpo por la ciudad en un claro intento de revitalizar su culto convirtiendo a san Julián en patrón de la ciudad y la diócesis. A pesar de las curaciones milagrosas y la afluencia de feligreses a ver el cuerpo del santo y de los intentos por hacerse con una reliquia, las expectativas del cabildo no parecieron cumplirse; sin embargo, el cabildo inició el proceso de canonización en 1540 y en 1551 con la celebración de la fiesta el cinco de septiembre, día de feria en Cuenca. El concejo empezó a interesarse por el santo y a difundir su devoción. Algunos pequeños tropiezos y reticencias aparte, a finales del siglo XvI, en 1595, la santidad del obispo fue anunciada. Se reivindican de este modo los orígenes cristianos de la ciudad y se explica la importancia del episcopado y su labor en la ciudad sacralizando el territorio ${ }^{83}$.

80. Ainsa, D.: Translacion de las reliquias del glorioso pontifice S. Orencio hecha de la ciudad de Aux a la de Huesca, su cara y nada patria... Huesca, Juan Pérez de Valdivielso, 1612, p. 9, citado en Gómez Zorraquino, J. I.: Los santos Lorenzo y Orencio..., op. cit., p. 11.

81. La hagiografía del santo siempre ha contemplado su origen burgalés, vid. Cofiño, I.: «La devoción a los santos...», op. cit., p. 360, nota 16, donde recoge las principales biografías del santo desde la de Francisco Escudero de 1595; sin embargo, más recientemente se afirma que fue un mozárabe toledano, vid. Jiménez Monteserín, M.: Vere pater..., op. cit., pp. 17-18.

82. Cofiño, I.: «La devoción a los santos...» op. cit, pp. 361-362 y nota 23.

83. Jiménez Monteserín, M.: Vere pater..., op. cit. Nalle, S. T.: «Desde el olvido a la fama: el culto a san Julián en los siglos Xvi y XvII», Almud. Revista de Estudios de Castilla La 
A partir de este momento proliferaron la construcción de ermitas e iglesias y se difundió su imagen con lienzos y tallas diversas y también su carácter de liberador de la peste al invocársele en varias ocasiones con motivo de las epidemias que asolaron Castilla y otros puntos de la península a finales del siglo xvi. Tuvo especial arraigo en Burgos, Murcia o Málaga.

En la periferia de la ciudad de Ávila existe una ermita dedicada a san Segundo. Allí, en 1519, los cofrades de san Sebastián, advocación anterior de la ermita, descubrieron el cuerpo de san Segundo, el primer obispo de Ávila ${ }^{84}$. El cabildo catedralicio no consiguió hasta 1594 su traslado a la catedral debido a la negativa de la muy poderosa cofradía que lo encontró. En la invención de un santo como san Segundo juegan un papel muy destacado la cofradía, con deseos de protección y ayuda, las elites eclesiásticas por promocionar la sede en antigüedad con su primer obispo y las elites ciudadanas presentándole como señal de elección divina. Pero como señala Cátedra, Ávila dio un golpe de efecto frente a Segovia, que un año antes había encontrado el cuerpo de su patrón san Frutos, con el hallazgo del cuerpo de san Segundo al anteponerse en jerarquía santa, ya que este último era uno de los Varones Apostólicos, uno de los primeros discípulos de Santiago en su predicación por Hispania y nombrado obispo en los primeros tiempos del cristianismo ${ }^{85}$. San Segundo estaba por tanto por delante de santos más modernos como san Frutos (642-715) o los antiguos patronos de Ávila, san Vicente, santa Sabina y santa Cristeta ${ }^{86}$. Sin duda este obispo fundador y prototipo de los avances de la cristianización de la Hispania romana colmó las expectativas de la clase dirigente abulense, pero también de los artesanos y del común en momentos convulsos para la ciudad y para el reino (los prolegómenos de la revuelta de las Comunidades) y con el tiempo se convirtió en fuente de legitimidad histórica, símbolo de poder y manantial de beneficios taumatúrgicos.

Mancha, 1, 1981, pp. 25-41; id.: «A Saint for All Seasons: The Cult of San Julián», en CruZ, A. J. y Perry, M. E. (eds.): Culture and Control in Counter-Reformation Spain. MinneapolisOxford, 1992, pp. 25-50.

84. Cianca, A. de: Historia de la vida, invención y milagros y traslación de San Segundo, primero Obispo de Ávila... Madrid, Luis Sánchez, 1595; CÁtedra, M.: Un santo para una ciudad. Ensayo de antropología urbana. Barcelona, 1997.

85. AragüÉs, J.: «Los discípulos de Santiago. Tradiciones, equívocos y fabulaciones en la fábrica de un entorno nacional (I)», en Cazal, F., Chauchadis, C. y Herzig, C. (eds.): Pratiques hagiographiques dans l'Espagne du Moyen âge et su Siècle d'Or. Toulouse, 2005, pp. 221-233; id.: «Los discípulos de Santiago. Tradiciones, equívocos, fabulaciones (II)», en El texto infinito: reescritura y tradición en la Edad Media y en el Renacimiento. Salamanca, SEMYR, 2014, pp. 299-311.

86. Cátedra, M.: Un santo para una ciudad..., op. cit., p. 68. 
Ejemplo de patronazgo vinculado a los intereses de la curia y de los capítulos catedralicios, unido a la política de los reyes cristianos de restauración eclesiástica y mitras obispales en las catedrales de ciudades conquistadas a los musulmanes es san Valero en Zaragoza. El conocimiento que tenemos de este santo y de otros provenientes de la jerarquía eclesiástica como él, parte en primer lugar de los episcopologios de las diferentes diócesis. Efectivamente, la confección de episcopologios fue algo habitual en las sedes episcopales y de la de Zaragoza conocemos varios de los siglos XVI y xvII, siendo de los más significativos el que incorpora el abad Martín Carrillo precisamente en su Historia de san Valero ${ }^{87}$. Este listado es un nuevo acomodo de una edición latina con el catálogo de obispos de Zaragoza que, aunque editado en 1611, estaba escrito ya en $1603^{88}$. El padre Murillo ${ }^{89}$ en su Fundación de la capilla angélica y Excelencias de la ciudad de Zaragoza también trae un listado con brevísimas semblanzas de obispos y arzobispos. En los siglos siguientes habrá nuevas ediciones de estos listados e incluso algunos manuscritos que recopilarán más noticias de los prelados zaragozanos y aragoneses ${ }^{90}$.

El obispo Valero es patrón de la ciudad y de la catedral del Salvador. Este santo, obispo de la ciudad de Zaragoza ${ }^{91}$, vivió a caballo de los siglos iII y iv. Se le da como natural de Zaragoza y Carrillo aporta los testimonios de un buen número de escritores (Prudencio, Villegas, Ribadeneyra, Ambrosio de Morales, Garibay, Baronio...), aunque también dedica unas líneas a rebatir la opinión del obispo Martín García, que afirmó era oriundo de Grecia y que la metropolitana era la iglesia de Santa María la Mayor o iglesia de Nuestra Señora del Pilar ${ }^{92}$. Se conoce su participación en el Concilio de Elbira (Granada) hacia el año 306 y también se sabe que estuvo en Valencia durante las persecuciones de Diocleciano en compañía de su diácono Vicente que sufrió martirio. No abundan las noticias históricas del obispo, al que en los relatos antiguos llaman confesor o mártir, en este último caso «por tantos trabajos como padeció en la cárcel y en

87. Carrillo, M.: Historia del glorioso san Valero obispo de la ciudad de Çaragoça..., op. cit., pp. 223-300: Obispos y arzobispos desde el año 40 hasta 1615.

88. CARrillo, M.: Catalogus antistitum caesarangustanorum, qui Romanorum, Gothorum, Arabum et aliorum post ipsos Regum temporibus...usque ad annum 1611. Cagliari, Martinus Saba, 1611.

89. Murillo, D.: Fundación milagrosa de la Capilla Angelica y Apostolica..., op. cit.

90. Real Academia de la Historia [RAH]. Col. Traggia, Ms. 9/5221: ProAño, I.: Libro de noticias de obispos y arzobispos de Zaragoza, desde san Anastasio hasta el año 1687 y de lo sucedido en Daroca y sus iglesias, compuesto por don... cit.

91. Carrillo, M.: Historia del glorioso san Valero obispo de la ciudad de Çaragoça..., op.

92. Ibid., pp. 4-7. 
su destierro» ${ }^{93}$. El destierro, según su biógrafo, se produjo por orden de Daciano y se le prohibía volver a Zaragoza ni a ningún lugar poblado con más de veinte casas. Con la subida al poder del emperador Constantino y la ausencia de persecuciones se le permitió volver a su iglesia y para algunos murió en ella en el 315.

Enterrado en el castillo de Estrada se perdió su memoria hasta que en 1050 se trasladaron a la iglesia de san Vicente en Roda de Isábena lo que se suponían eran sus restos. Con la conquista de Zaragoza por Alfonso I y para una correcta restauración de la mitra cristiana se pidieron las reliquias del obispo, a quien considerarán patrón de la iglesia zaragozana, y la catedral de Roda envió un brazo en 1121 y en 1170, en tiempos de Alfonso II, la cabeza que, más adelante, fue guardada en el relicario que el Papa Luna envió desde Aviñón y que se exhibía en las procesiones de la catedral junto con los de san Vicente y san Lorenzo, también remitidos por Benedicto XIII en 1405. La importancia que las reliquias de san Valero tuvieron para los monarcas y el significado primigenio para la iglesia zaragozana lo manifiesta la carta que el futuro cardenal Gerónimo Xavierre envió desde Jaca el 2 de febrero de 1598 a Felipe II, a petición del monarca, sobre las reliquias de san Valero existentes en Roda de Isabéna. En dicha carta, después de resumir los datos esenciales de la vida y muerte del obispo, enumera los siete huesos que conservan en la iglesia de san Vicente: los fémures, sacro, varias «canillas» y huesos redondos de la rodilla. El resto del cuerpo parece haber sido dado a diferentes prelados y eclesiásticos. De antiquísima (aunque de su inicio no hay memoria) se califica a la cofradía de san Valero, con prerrogativas, oficios de piedad y siete años de indulgencias ${ }^{94}$ concedidas por rezos en determinados días del año vinculados con san Vicente, el propio san Valero, san Hermenegildo y la Transfiguración (fiesta esta última importante en la Seo porque esta es una de las escenas del retablo mayor). El arzobispo Pedro de Luna fue uno de los que mayores beneficios concedió a los cofrades en marzo de 1320. La devoción a san Valero la basan los historiadores antiguos en los milagros que obraron sus reliquias con diversos endemoniados, tanto en Zaragoza como en otras localidades donde se invocó al santo, en la antigüedad de su episcopado y la tradición continuada tras el paréntesis de la presencia musulmana en la ciudad y en las múltiples procesiones en las que son requeridas las cabezas relicarios de La Seo, entre las que destaca la del 29 de

93. Dormer, D.: Dissertacion del martyrio de santo Domingo de Val seise o infante de coro de la santa iglesia metropolitana de Zaragoza en el templo del Salvador... Zaragoza, Francisco Revilla, 1698.

94. Ibid., p. 153. 
enero. En 1717 Vidal recuerda que la ciudad hizo voto de guardar perpetuamente fiesta como se guardan las fiestas colendas ${ }^{95}$.

Otro tipo de hombres santos que llegaron a ser patronos de las ciudades fueron los eremitas, como san Frutos (642-715) ${ }^{96}$ en Segovia o san Saturio (493-570) en Soria. Trasladados, según la tradición, los restos del primero y de sus hermanos Valentín y Engracia, en el siglo xII, a la catedral, sin embargo se perdió su memoria hasta que fueron hallados durante el obispado de Juan Arias de Ávila (entre 1461 y 1497) y llevados en procesión por la ciudad y nuevamente depositados en una arca a la vista de los fieles en la catedral. La procesión, la veneración en la catedral y la edificación de una nueva capilla para albergarlos fueron hechos importantes para fomentar la devoción. Con la revolución de las Comunidades los capitulares de Segovia se refugiaran en santa Clara y las reliquias fueron trasladadas al Alcázar. Superados los problemas con obispo y alcaide, se logró el traslado del Alcázar a la iglesia de santa Clara pedido por los capitulares, ya que se estaba haciendo una nueva catedral. El 25 de octubre de $1522^{97}$ se hizo una procesión solemne con las reliquias y los fieles pudieron venerar y tocar las reliquias de su patrón en claro significado de identidades compartidas.

El caso de san Saturio ${ }^{98}$, según la tradición un noble que dejó todas sus posesiones y se retiró a una cueva cerca del Duero donde murió y donde se encontraron sus restos en la segunda mitad del siglo Xvi, es similar a tantos otros. Parece que en el siglo XII había un oratorio llamado de san Miguel que cambió posteriormente el nombre por el de san Saturio. Se conservan escrituras y acuerdos municipales y del cabildo de la iglesia de san Pedro para reparar en 1553 «la ermita de san Miguel de la Peña, donde está el cuerpo santo que dicen de san Saturio» ${ }^{99}$. Desde esta fecha al menos se realiza una procesión con las reliquias. También hubo nuevas reparaciones de la iglesia y del eremitorio a lo largo del siglo xviI. Desde el 25 de

95. Vidal, L.: Politicas ceremonias de la imperial ciudad de Zaragoza. Zaragoza, Pascual Bueno, 1717, p. 8.

96. Orche, J. de: Historia de la vida del glorioso San Frutos, patrón de la ciudad de Segovia y de sus hermanos San Valentin y Santa Engracia... Valladolid, Christoval Lasso Vaca, 1610; SÁnchez Ferro, P.: «La ciudad en procesión: estudio sobre traslación de reliquias (Centrado en el ejemplo de san Frutos, patrón de Segovia)», Espacio, Tiempo y Forma, Serie IV Historia Moderna, T. 12, 1999, pp. 47-65.

97. SÁnchez Ferro, P.: «La ciudad en procesión...», op. cit., pp. 60-65.

98. Biblioteca Nacional. España. [BNE], Mss. 17903. Gutiérrez De Castilla, F.: Epitome de la vida del glorioso anacoreta san Saturio, hixo y patrón de la mui noble Ziudad de Soria... 1716; Sanz Serrano, A.: Historia y descripción de la cueva y ermita de san Saturio, Soria, 1915 .

99. Jiménez Zamora, V.: «Culto de Soria a san Saturio y significado religioso de su ermita», Revista de Soria, 14, 1996, pp. 65-76. 
septiembre de 1626 es fiesta votiva la de san Saturio para celebrar el 2 de octubre, escribiéndose al obispo para que se guarde como tal en la ciudad; dos años más tarde, en 1628, fue nombrado patrono de la ciudad por aclamación popular con festejos que incluyeron espectáculos taurinos. En 1646 el cabildo de san Pedro y la ciudad encargaron una arqueta para guardar las reliquias con varias llaves y la ciudad protestó porque el cabildo no le entregaba la suya. Discusiones como estas son una constante entre los distintos poderes ciudadanos y eclesiásticos por el control de las reliquias. Finalmente en 1743 queda solemnizado el culto y patronazgo por Benedicto XIV de acuerdo a los decretos y bulas de los Papas anteriores que obligaron a elegir como patronos a santos canonizados y a celebrarlo como fiesta de precepto, es decir, como festivo para los trabajadores. Con ese motivo se celebraron fiestas en la ciudad con procesiones, fuegos y toros ${ }^{100}$. Unos años antes, el capellán de Pozuelo de Alarcón, el doctor Juan Antonio Simón, escribió un libro sobre san Saturio de mil páginas editado en 1713 el primer volumen y en 1739 (póstumamente) el segundo, cuyo contenido repasa la vida y los actos en torno al santo durante la Edad Moderna ${ }^{101}$.

\section{La Virgen del Pilar, patrona de Zaragoza en el siglo XVII}

El modelo más depurado de patronazgo en la Edad Moderna de una advocación de la Virgen lo constituye sin ninguna duda la Virgen del Pilar. El texto de la leyenda se encuentra en las páginas finales de los Moralia in Job de Gregorio Magno, códice que data de finales del siglo XIII o principios del XIv ${ }^{102}$ copiado, verosímilmente, en esas mismas fechas, por Pedro Poncas de Roncal ${ }^{103}$, aunque se dice fue traído desde Roma por el obispo Tajón a mediados del siglo vir. El relato, lleno de anacronismos, narra cómo es enviado el apóstol Santiago a predicar a Hispania, su itinerario peninsular, la conversión de ocho personas en Zaragoza y la aparición de la Virgen sobre un pilar de mármol una noche en la ribera del

100. Gutierrez Caravantes, M.: Descripción de las fiestas que celebró la ciudad de Soria al glorioso san Saturio, su hijo y patrón, con motivo de aver logrado la concesión de su rezo, de primera clase y fiesta de precepto para dicha ciudad... Calatayud, Gabriel Aguirre, 1744.

101. Simón, J. A.: El anacoreta canonizado. San Saturio, eremita, natural y patrono de la antiquissima, invicta, noble y leal ciudad de Numancia, aora Soria..., Parte Primera, Madrid, Imprenta Real, 1713; Parte Segunda, Madrid, Imprenta Real, 1739.

102. Magallón, A. I. y Martín, J. C.: «La leyenda de la venida de la Virgen a Zaragoza (BHL 5388): Edición crítica y estudio», Hagiographica, XXI, 2014, pp. 53-84.

103. Archivo Capitular del Pilar [ACP], Moralia in Job de Gregorio Magno, 2 vols. [sin signatura], el relato en T. I., pp. 274v-5r.; Magallón, A. I. y Martín, J. C.: «La leyenda de la venida de la Virgen...», op. cit., pp. 54-55. 
río con dos coros de millares de ángeles que cantaban Maitines, diciéndole que debía edificar un templo allí mismo protegiendo el pilar que traía, enviado por el mismo Jesucristo desde el cielo por manos de ángeles. Sigue el relato diciendo que volvió la Virgen a Jerusalén y que Santiago construyó un templo de ocho pasos por dieciséis, colocando allí el pilar y un altar e intitulándolo de Santa María del Pilar, ordenando para su cuidado a un presbítero entre los discípulos que había convertido.

En el siglo xvi tres textos coparán el interés pilarista desde Zaragoza. Serán, fundamentalmente, la edición príncipe de la Apparitio $b$. Mariae de Pilari en $1542^{104}$, la edición del Index del canónigo Llorente de $1591^{105}$ y la Fundación de Luis Díez de Aux de 1593 ${ }^{106}$.

Ciertamente encontramos el interés del cabildo por la devoción, pero sobre todo por la reivindicación de la predicación apostólica y de su presencia con la Virgen en Zaragoza. Estamos ante el episodio seminal del cristianismo peninsular y además en el momento en que los llamados varones apostólicos, los primeros discípulos del Hijo del trueno, todos reunidos en Zaragoza, marcharán a predicar y a ocupar las primeras mitras episcopales en ciudades hispanoromanas. En los siglos XVI y XVII este hecho permitirá a muchas de estas sedes reivindicarse con el primigenio carácter de su conversión y la ocupación de su silla obispal por los varones apostólicos. El cabildo financiará muchos de los textos que recogen la leyenda y que saldrán a la luz, en su versión latina y en su versión traducida con carácter más didáctico y de uso escolar ${ }^{107}$.

Es en el contexto histórico de mediados del siglo xv, con la redacción del Libro de los Milagros, la bula calixtina de 1456, la peregrinación de la reina Blanca de Navarra en 1433, la restauración tras el incendio del año siguiente con el apoyo económico de esta monarca y la realización de la imagen de la Virgen (hacia

104. Hic continetur quomodo et per quos edificata fuit ecclesia beate Maria maioris et de Pilari civitatis Cesaranguste regni Aragonum. Zaragoza, 1542. El ejemplar, único conocido, actualmente se conserva en Cortes de Aragón. Biblioteca. L 1011 F. Antig.

105. Llorente, B.: Index auctorum qui adventu sancti Iacobi Apostoli in Hispaniam, praedicationes, translationes, miraculis, E discipulis, ac de fundatione Ecclesiae Sanctae Mariae Maioris de Pilari... Zaragoza, Lorenzo Robles, 1591.

106. Díez De Aux, L.: Fundación de la capilla y cámara angelical de Nuestra Señora del Pilar de la ciudad de Çaragoça... Caragoça, Miguel Ximeno Sánchez, 1593. Hay edición crítica, Serrano Martín, E.: El Pilar, la historia y la tradición..., op. cit., pp. 186-270.

107. Historia miraculosae fundationis sanctae capellae ecclesiae beatae Mariae et de Pilari, primae cathedralis civitatis Caesarangustae... 1646; Historia de la milagrosa fundación de la Santa Capilla de Nuestra Señora Santa María del Pilar de Zaragoza por el apóstol Santiago... 1646. Para un comentario sobre los distintos públicos de estos textos y sus peculiaridades editoriales: Serrano Martín, E.: El Pilar, la historia y la tradición..., op. cit., pp. 15 y ss. 
1435-1443), obra de madera dorada y policromada de estilo gótico borgoñón y atribuida a Juan de la Huerta ${ }^{108}$, el apoyo eclesiástico y ciudadano bajo el episcopado de Dalmau de Mur y también la fijación de las imágenes sobre la aparición como la que se ejecuta por vez primera en el relicario de plata del busto de san Braulio realizado entre 1456 y $1461^{109}$, donde podemos situar el definitivo despegue de la devoción y la estrategia capitular de avanzar en su influencia ciudadana y religiosa con los argumentos desarrollados en los escritos del siglo xvi y que tantos réditos les darán en lo tocante a la primacía catedralicia, el cristianismo de origen apostólico y el primer templo mariano de la cristiandad.

Sin duda alguna el cabildo del Pilar (ya con notables discrepancias con el cabildo catedralicio de La Seo) y sectores importantes de la población y de su oligarquía urbana auparon la devoción. Una familia significativa en el concejo, como jurados y consejeros, y entre la intelectualidad urbana, fueron los Díez de Aux. Un miembro de esta familia, Luis Díez de Aux, es el autor de una obra, la Fundación, ya citada, que servirá de origen a todas las cartelas que ampliamente difundidas serán el vehículo de enseñanza y trasmisión de la leyenda en toda la primera mitad del siglo xvir. De esta familia también hay varios canónigos ${ }^{110}$. También el canónigo Llorente con su Index de 1593 aportará su erudición y será la base que utilizará el cabildo del Pilar y el concejo de la ciudad para el catálogo de 180 autores que defendieron la tradición y que presentaron por medio del mercedario padre Cavero al Cardenal Orghi el año 1723, manteniendo controversias con el padre Lambertini. En la segunda mitad del siglo xvi el relato de la leyenda del Pilar aparece recogido en muchos textos de cronistas o historiadores como Pedro Antonio Beuter, Jerónimo Románo, Ambrosio de Morales, ya citados.

También será importante la existencia de una cofradía de santa María la Mayor, de gran prestigio social, que agrupará a las elites zaragozanas vinculadas al concejo de la ciudad ${ }^{111}$. Otro de los factores que impulsaron la devoción fue el

108. Lacarra, M. ${ }^{a}$ C.: «La devoción a Santa María del Pilar de Zaragoza durante la Baja Edad Media», en El Pilar es la columna. Historia de una devoción, Zaragoza, 1995, pp. 23-46, en p. 30.

109. Ainaga, M. T. y CRiado Mainar, J.: «El busto relicario de san Braulio (1456-1461) y la tradición de la venida de la Virgen del Pilar a Zaragoza», Aragón en la Edad media, 20, 2008, pp. 65-84.

110. Biografía de Juan de Aux en Archivo Capitular de La Seo. Ipas, J.: Catálogo chronologico de los priores, dignidades i canónigos del santo templo del Pilar de Zaragoza en tiempo de la regularidad. Hizole el recionero Joseph Ypas, secretario del Ilustrisimo Cavildo en el año de 1786 .

111. Jarque, E.: Los procesos de limpieza de sangre en la Zaragoza de la Edad Moderna. Zaragoza, 1983. 
fervor inmaculista y mariano que a comienzos del siglo xviI respiraba la ciudad y las instituciones ciudadanas y al que no era ajeno el franciscano Pedro González de Mendoza, arzobispo de Zaragoza entre 1616 y 1623 . Hijo de los príncipes de Éboli, fue un defensor de la Inmaculada a la que dedicó varios tratados. Durante su episcopado, en 1619 el Concejo zaragozano hizo voto y juramento inmaculista, así como la universidad y diversas congregaciones ${ }^{112}$. El cabildo del Pilar lo realizó el 12 de mayo de $1619^{113}$. También en este comienzo de siglo vieron la luz diversos tratados escritos por carmelitas ${ }^{114}$ a favor de la Inmaculada y nuevos escritos sobre la Virgen del Pilar, como el del padre Diego Murillo de $1616^{115}$. También hay que contextualizarlo en los debates sobre el patronazgo de Teresa de Jesús, canonizada en 1622, y Santiago ${ }^{116}$, que se entrelazan con otros, intensos $\mathrm{y}$ desabridos en momentos, entre los cabildos compostelano y cesarausgustano con un sector de la Curia romana por las consideradas inoportunas intervenciones del cardenal Bellarmino y las modificaciones en el Breviario romano por parte del cardenal Baronio con sus obras Annales Eclesiastici (1588-1607) y Martyrologium Romanum (1586-1589) ${ }^{117}$.

El más importante puntal en la rápida e intensa difusión de la devoción pilarista y en la gran influencia del cabildo de Santa María, es sin duda el llamado milagro de Calanda en $1640^{118}$ : la restitución, por intercesión de la Virgen, de la

112. Sobre juramentos inmaculistas, Polo Carrasco, J.: Los juramentos inmaculistas en Zaragoza, 1617-1619. Zaragoza, Caja de Ahorros de Zaragoza, 1987.

113. ACP. Alm. 1, Cax. 1, Lig. 1, nº 27.

114. San José, Fray J. de: Historia del Carmelo descalzo... Madrid, Francisco Martínez, 1637; Santa Teresa, Silverio de: Historia del Carmen descalzo en España, Portugal, y América. Burgos, Monte Carmelo, 1935-1953, 15 Vols.

115. Murillo, D.: Fundación milagrosa de la Capilla Angelica..., op. cit.

116. REY, O.: «La disputa del patronazgo de la Monarquía, ¿Santiago o santa Teresa?», en Martínez Millán, J. y Visceglia, M. A. (eds.): La Monarquía de Felipe II. La Casa del Rey. Madrid, 2007-2008, Vol. I., pp. 227-46; ReY, O.: «Teresa, patrona de España», Hispania Sacra, LXVII, 2015, pp. 531-573; Rowe, E. K.: Saint and Nation: Teresa of Avila, Santiago, and Plural Identities in Early Modern Spain. Pennsylvania, 2011.

117. Guazzelli, G. A., Michetti, R. y Scorza, F. (eds.): Cesare Baronio tra santità $e$ scrittura storica. Atti del Colloquio Internazionale di Studi (Roma, 25-27 gingno 2007). Barcelona, Roma, 2012; Rey, O.: Los mitos del apóstol Santiago. Santiago de Compostela, 2006; MárQueZ Villanueva, F.: Santiago: trayectoria de un mito. Barcelona, 2004.

118. Sobre el milagro de Calanda hay una bibliografía abundante; resultan interesantes por uno u otro motivo Sancho IzQuierdo, M.: El milagro de Calanda. Zaragoza, 1940; Estella, E.: El milagro de Calanda, estudio histórico crítico. Zaragoza, 1951; Aina, L.: El milagro de Calanda a nivel histórico. Zaragoza, 1972; Domingo, T.: El Milagro de Calanda. Zaragoza, 2009; y Domingo, T. y CasorRán, E.: El milagro de Calanda y otros favores extraordinarios de Nuestra Señora del Pilar. Zaragoza, 2013; GAscón, A. y Briongos, Á.: El milagro del cojo de Calanda. La génesis de un mito. Zaragoza, 2015. 
pierna cortada a Miguel Pellicer. A partir de este momento el Cabildo pilarista, involucrando a la ciudad, comenzó a desplegar una actividad diplomática sin precedentes que tendrá como colofón la extensión del oficio propio a todos los dominios del Rey Católico y su elevación a rito doble de primera clase y con octava para todo el Reino en 1807 por parte del papa Pío VII. Una de las primeras actuaciones fue el ofrecimiento del patronazgo de la ciudad por parte del concejo, ya tras los decretos y normativa vaticana, incluida la fiesta de precepto en 1642. Ya los jurados de la ciudad habían acordado guardar fiesta el 12 de octubre, en un primer momento el 15 de mayo, día de los convertidos, y todo ello a pesar de las reticencias del cabildo de La Seo. El 8 de mayo de 1613 el Capítulo y Consejo hizo voto de guardarla perpetuamente, en toda la ciudad, como se guardan las otras fiestas colendas y se comprometieron a hacer procesión general a la dicha iglesia del Pilar. Renovado el juramento en 1653, las Cortes de Aragón en 1678 la votaron como patrona del reino.

El milagro de Calanda, la restitución de la pierna amputada años atrás a Miguel Pellicer en la noche del 29 de marzo de 1640, tuvo un impacto importante en todo el orbe católico y fue utilizado como ariete contra el protestantismo y para los intereses del cabildo pilarista. Tuvo una rápida difusión impresa en forma de carteles, libros y opúsculos. Felipe IV se convirtió en impulsor de la ampliación del templo del Pilar y los escritos de sor María Jesús de Ágreda, instando al rey a visitar la Capilla en Zaragoza y ofreciendo una fecha exacta para la aparición de la Virgen en Zaragoza, lograron hacer imparable la devoción y la influencia política y religiosa del templo hasta el punto que se formalizó la unión de los cabildos de La Seo y del Pilar. La importancia que el milagro tuvo como baluarte contrarreformista lo dejó claro el propio Amada en su compilación:

Paso al año 1640 en que vio España, y admiró Europa el Milagro, más estupendo y calificado que ha obrado Dios en muchos siglos, no sin grande aprovechamiento, en prueba de resurrección de la Carne, que niegan muchos hereges de nuestro tiempo en Inglaterra, Olanda y Alemania ${ }^{119}$

al tiempo que exponía el valor de los sacramentos. Eran más argumentos ante los herejes y significa el fortalecimiento de la ortodoxia, ya que de este modo se favorece al buen católico.

119. Amada, J. F. de: Compendio de los milagros de nuestra Señora del Pilar de Zaragoza, primer templo del mundo edificado en la ley de Gracia, consagrado con asistencia personal de la Virgen santísima, viviendo en carne mortal... Zaragoza, Herederos de Agustín Verges, 1680. Hay una segunda edición, Zaragoza, Oficina de Mariano Miedes, 1796. Cito por la edición de 1796, p. 242. 
Con el milagro hay un interés de la Monarquía por vincularlo a su política.

La importancia que va adquiriendo el capítulo del Pilar, la propia basílica, la devoción pilarista y la influencia ciudadana la podemos apreciar sin ningún género de dudas en las actuaciones, muy favorables, de la Monarquía y de sucesivos decretos papales. Entre los hitos encontramos el festejo del 12 de octubre con su procesión con la misma solemnidad que la del Corpus Christi ${ }^{120}$, la concesión de Inocencio XI en 1680 de indulgencia plenaria a todos los fieles que asistan a la fiesta en la mencionada fecha ${ }^{121}$, la ampliación de la vieja fábrica gótica del Pilar con planos del arquitecto real y con mecenazgo real y en 1681 se celebra con gran pompa la colocación de la primera piedra del nuevo templo y la traslación del tabernáculo en 1718. El rezo con octava se pidió a Roma en diversas ocasiones desde 1678 con el apoyo de importantes apellidos de la elite zaragozana y aragonesa y finalmente Inocencio XIII lo aprobó en $1720^{122}$. En 1723 el mismo Papa concedió el oficio propio por la aparición de la Virgen ${ }^{123}$. La celebración litúrgica de la octava, las procesiones -con asistencia del concejo- y los festejos propios de otras celebraciones -toros, encamisadas, carros triunfales, teatros, luminarias y fuegos artificiales entre otros- hicieron de esta fiesta, a lo largo de los siglos XVIII y XIX, un referente ciudadano y una devoción popular. Al mismo tiempo que crecía su implantación, primero por los territorios aragoneses y por los españoles después, se iba pergeñando un modelo celebrativo que, a la postre, tampoco era muy diferente a otras solemnidades.

120. Biblioteca Nacional de España [BNE]. VE/215/1: Bulla de la unión de las dos santas iglesias de nuestra Señora de el Pilar, y el Salvador de la ciudad de Zaragoza por la Santidad de Clemente X. Fecha en Roma a 3 de los idus de febrero de el año de 1676. Obtenida a suplica del rei nuestro señor don Carlos II y executada a instancia de su abogado fiscal. 22 p. Sin lugar ni fecha de impresión.

121. Gutiérrez Lasanta, F.: Historia de la Virgen del Pilar. 10 vols. Zaragoza, 1971-1987, vol. V, pp. 302 y 303.

122. España sagrada. Tomo XXX. Contiene el estado antiguo de la santa Iglesia de Zaragoza... su autor el P. Fr. Manuel Risco... Madrid, Imprenta de don Antonio de Sancha, 1775, pp. 87 y ss. Sobre Ferreras, Serrano Martín, E.: «Silentium facite. El final de la polémica y el discurso en torno a la Virgen del Pilar», Hispania, 248, 2014, pp. 687-714.

123. Escuder, J. F.: Relacion Historica y panegyrica de las fiestas que la ciudad de Zaragoza dispuso con motivo del decreto, en que la Santidad de Inocencio XIII concedio para todo este arzobispado, el Oficio propio de la Aparicion de Nuestra Señora del Pilar... Zaragoza, Pasqual Bueno, [1724]. [Edición facsímil, Zaragoza, Ayuntamiento, 1990, con introducción de Eliseo Serrano Martín.]. 


\section{Santos Patronos modernos: El franciscano Pedro Regalado y LA DOMi- NICA RosA DE LIMA}

El franciscano Pedro Regalado fue canonizado por Benedicto XIV en una ceremonia múltiple, con cinco santos subiendo a los altares el 29 de junio de 1746. Recordaba a la ceremonia de hacía más de un siglo en la que fueron canonizados, según la crítica romana, cuatro españoles y un santo: Teresa de Jesús, Ignacio de Loyola, Francisco Javier, Isidro y Felipe Neri elevados a los altares el día 15 de marzo de 1622 por el papa Gregorio XV. Pero en esta ocasión los canonizados responden a una retrato bien distinto; no son los santos militantes o fundadores de las grandes órdenes reformadas o nuevas, sino cuatro hombres y una mujer cuyas virtudes heroicas les acercan a acciones vinculadas a la escuela, a la sanidad, a la asistencia de sujetos desfavorecidos como pobres, prostitutas o presos, en definitiva, a actividades en asociaciones caritativas y asistenciales. Es otra tipología hagiográfica que presenta al santo activo socialmente. Además parece que el control inquisitorial de la santidad durante el siglo xvII quiso cerrarlo el Papa Benedicto XIV, de labor canonizadora importante, cuando elevó, como se ha dicho, a los altares el 29 de junio de 1746 a cinco santos, de algunos paralizado su proceso por efecto del Santo Oficio ${ }^{124}$. Fueron los capuchinos Fidel de Sigmaringen ( $\left.† 1622\right)$ y Giuseppe da Leonessa ( $\dagger 1612)$, la monja dominica del convento fundado en Florencia por monjas devotas de Savonarola, Catalina de Ricci $(\dagger 1590)$, el franciscano español patrón de Valladolid Pedro Regalado $(\dagger 1456)$ y el sacerdote fundador de la orden hospitalaria de los Camilos, Camilo de Lelis $(\dagger 1614)^{125}$.

La canonización de Pedro Regalado (Valladolid 1390-Aguilera 1456) ${ }^{126}$ y el patronazgo de la ciudad de Valladolid siguieron los pasos marcados por la normativa emanada de la Congregación de Ritos y de los sucesivos decretos

124. Gotor, M.: Chiesa e società..., op. cit., pp. 99 y 125 .

125. Relacion individual de la solemne canonización de cinco santos que son Fidel de Sigmaringa martyr de la orden de menores capuchinos, Camilo de Lelis fundador de los clérigos regulares ministros de los enfermos, Pedro Regalado de la Orden menor de la Observancia de san Francisco, Jospeb de Leonesa semejantemente de la Orden menor capuchinos y Cathalina Rizi, monja profesa de la Orden de santo Domingo. Celebrada el dia 29 de junio de 1746, Antonio Perez Soto, imp., 1746.

126. Daza, fray A.: Excelencias de la ciudad de Valladolid con la vida y milagros del santo fray Pedro Regalado... Valladolid, Juan Lasso de la Peña, 1627; Monsaval, M.: Historias de las heroicas virtudes y aclamación de los estupendos milagros, vida, muerte y culto de san Pedro Regalado. Valladolid, 1684; SANGRAdor y Vitores, N.: Vida de san Pedro Regalado patrón de la Valladolid. Oviedo, 1854; EgIdo, T.: San Pedro Regalado. Valladolid, Diputación de Valladolid, 1983; «Procesos de beatificación y canonización de san Pedro Regalado», Archivo Ibero-Americano, 12, 1920, pp. 5-20. 
y bulas de los papas en torno a los procesos informativos y apostólicos que debían seguirse, de non cultu, del tiempo transcurrido, de la beatificación y posterior canonización, de la petición y votación del patrón y de la sanción papal del mismo ${ }^{127}$. Muerto en 1456 será en la segunda mitad del siglo cuando se realicen las informaciones y expedientes sobre la vida y milagros, aunque en 1492 se desenterró el cadáver en el convento de Aguilera para su traslado a la capilla mayor a un sepulcro costeado por la condesa de Haro. Cuando sacaron el cuerpo, como viene siendo habitual en todas las descripciones de época de casos de santidad, exhaló un suave olor y cuando le cortaron un brazo sangró y se recogieron paños empapados en sangre. De la mano se cortaron dos dedos que quedaron en el convento y el resto fue entregado a la reina Isabel la Católica que había ido a visitar la tumba. En diversas visitas a la tumba del franciscano, a miembros de la casa real se entregaron reliquias. Uno de los milagros después de muerto lo realizaron sus reliquias, que fueron llevadas a Aranda, donde el rey Felipe III se encontraba enfermo en 1610.

Como en todas las hagiografías sus autores destacan una infancia ya marcada para una vida de santidad, se habla de la legitimidad de su nacimiento, de su bondad y amistad con los pobres, de su caridad ofreciendo limosnas y de su pronta vocación, entrando en religión en la orden franciscana. Pronto se convirtió en coadjutor de fray Pedro de Villacreces, con quien fundó el convento de Aguilera y el de El Abrojo (en Laguna de Duero) y ambos con fray Pedro Santoyo fundan la regular observancia y la provincia de la Concepción. Entre sus virtudes y milagros el padre Daza destaca su virginidad, sus oraciones que hacía levitando y con fuego sobre el piso, tuvo el don de lágrimas y fue humilde, penitente y abrazó la pobreza. Fueron excesivos sus ayunos (hablaba de sus cuaresmas encadenadas a lo largo del año). Entre los milagros acaecidos antes de su muerte destacan la resurrección de un joven que quiso ser fraile y la humillación de un toro que se había escapado de las fiestas de Valladolid y embistió contra el santo y su acompañante. Este milagro lo vincula su biógrafo a la fe, a la práctica de esta virtud teologal, así como el andar sobre las aguas y pasar los ríos sin mojarse. Otro de los milagros atribuido a Pedro Regalado, pero también a muchos otros santos, es el de la conversión de comida en rosas ante preguntas más o menos incómodas. También se le atribuye el don de la profecía. Tras su muerte, la información para

127. BNE, Porcones / 1326/8. Interrogatorio, deposiciones y articulos sobre lo que han de ser examinados los testigos en la información plenaria que han de hazer los señores juezes apostólicos delegados de nuestro Santísimo Padre Urbano Papa VIII y de la Sagrada Congregación de Ritos, para la beatificación y canonización del siervo de Dios el venerable padre fray Pedro Regalado de la Orden de los menores del seráfico padre san Francisco de la Observancia. 
el expediente de canonización recoge más de 128 milagros que el escritor pormenoriza en los primeros seis meses y que cubren sanaciones diversas de tullidos, paralíticos, enfermos, ciegos y resurrecciones.

Valladolid quería un santo propio, nacido en la ciudad y que fuera su patrono. Iniciado el proceso, formado un expediente con escrituras de testigos el 15 de septiembre de 1562, fue testificado ante el Santo Oficio en 1595 y editada una de las Vitae en 1627, aclamándole como beato en 1683. Antes de la Vida del padre Daza, el obispo de Osma Martín Manso de Zúñiga mandó hacer en 1626 la primera información con autoridad ordinaria, movido por la veneración que los fieles daban a retratos y reliquias del siervo de Dios. El procurador de la Orden en Roma fray Juan de san Bernardino entregó al cardenal Peretti el expediente y este se votó favorablemente con el encargo de informaciones en los obispados de Valladolid y Osma en abril de 1627. Nombrados jueces eclesiásticos y notarios por ambos obispados, estos tenían el encargo de recoger testimonio y sobre todo de hallar nuevos milagros. Y así sucedió con la curación milagrosa de varios enfermos desahuciados. El 16 de noviembre de 1630 salió el decreto definitivo de las virtudes del santo en grado heroico. Se repartieron cuadros del santo, se abrieron láminas y se distribuyeron sus estampas por la Curia romana, pero en la verificación de uno de los cuatro milagros que eligió el promotor de la Fe había una contradicción en uno, al no poner el padre Daza en su Vida del santo los apellidos de uno de los beneficiados, con lo que se paralizó el proceso. Tras este revés, aunque el Papa permitió en un Breve de 12 de septiembre de 1630, seguir con el culto inmemorial al santo con sus reliquias, los promotores consiguieron enmendar el error reconocido por Daza, pero cuando quisieron proseguirlo el Breve Non cultu de Urbano VIII obligaba a nuevas informaciones y la necesidad de limosnas les hicieron desistir. Estuvo 44 años en suspenso, hasta que la reina Mariana de Austria a finales de 1672 autorizó la petición de limosna en toda España para proseguir la causa. El papa Clemente X, a 28 de septiembre de 1675, despachó cartas para que el obispo de Osma Antonio de Silva remitiese noticias del culto inmemorial. Con otros milagros de por medio y el trabajo de varios licenciados entre 1675 y 1680, finalmente el obispo de Osma dictó sentencia el 30 de septiembre en la que de manera solemne se declara que no se ha contravenido a los decretos de non cultu y que están

legítimamente probado que al dicho bienaventurado siervo de Dios fray Pedro regalado de la Orden de los menores y regular observancia de san Francisco se le ha dado y exhibido culto de mas de cien años y de tiempo inmemorial a esta parte ${ }^{128}$.

128. Monsaval, M.: Historias de las heroicas virtudes..., op. cit., pp. 390-391. 
En 1683 se logró de la Sagrada Congregación de Ritos el 24 de julio de 1683 el decreto conformativo de la sentencia del obispo de Osma y el 17 de agosto el annuit del Papa. En el decreto se encuentran los argumentos de la virtud heroica, los milagros auténticos y la fama notoria, pública y universal del santo varón. Finalmente, el 1 de marzo de 1684 el Papa concedió el rezo doble para toda la religión, semidoble para las ciudades de Valladolid y Osma, que extendió el día 17 de junio la Congregación a los tres obispados de Palencia, Osma y Valladolid y se señala el día de su rezo el 13 de mayo. Finalmente subió a los altares el 29 de junio de 1746 y la ciudad logró que fuera aclamado patrono por plebiscito y recibido el patronazgo con grandes fiestas y enorme gasto para las arcas municipales ${ }^{129}$. La devoción al santo de siglos atrás, las actuaciones de piedad popular, la posesión de las reliquias con su significado de realidad viviente y el prestigio que tal presencia dota a la ciudad que corresponde otorgándole igual fama, empeñándose, metafórica y realmente, son manifestaciones de una religiosidad contrarreformista expandida globalmente.

El caso del patronazgo de santa Rosa de Lima no corresponde a los modelos propuestos por la Santa Sede. Su causa fue abierta antes de los 50 años de su muerte y su culto autorizado antes de ser canonizada, otorgándole ser patrona de la ciudad de Lima y del reino de Perú al año siguiente de su beatificación en 1668 en una decisión que vincula a un proceso antiguo de cristianización cuando a las ciudades y reinos de Europa se les otorgaba santos patrones en muchos casos debido a la existencia en las referidas ciudades de sus cuerpos santos.

Isabel Flores de Oliva ${ }^{130}$ en el siglo nació el 20 de abril de 1586, cuarta hija del matrimonio de Gaspar Flores y María de Oliva, que tuvieron trece hijos. Muy pronto parece destacar por una vida de privaciones y ayunos y tiene contactos

129. Descripción de las sagradas glorias y festivos cultos que la muy noble y leal cindad de Valladolid ha publicado en celebridad de la deseada canonización de su hijo san Pedro Regalado, Valladolid, Alonso Riego, [1746]. Verde ramo del sacro laurel de Apolo, cortado en el ameno valle de Oletano... la ciudad de Valladolid solemnizo la canonización... san Pedro (dos veces) Regalado..., Pedro Luzan de Reboles, 1747.

130. Mújica Puntilla, R.: Rosa limensis: mística, política e iconografía en torno a la patrona

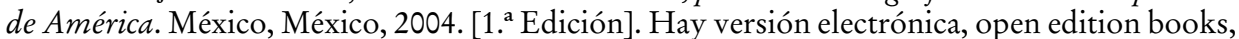
México, FCE-IFEA-Centro de Estudios Mexicanos y Centroamericanos, 2013. [Citaré por esta edición]. Es un trabajo que recopila la ingente producción bibliográfica sobre Santa Rosa de Lima y analiza los procesos y las implicaciones políticas y sociales de la canonización. Hansen, L.: Vida admirable de santa Rosa de Lima, patrona del Nuevo Mundo. Vergara, el Santísimo Rosario, 1929 [Es edición traducida de la de 1664], Oviedo y Herrera, L. A.: Vida de la esclarecida virgen Santa Rosa de Santa María, natural de Lima y patrona de el Peru... Madrid, Juan García Infanzón, 1711 [Reimpresión en México, Imprenta Real del Superior Gobierno, 1729]. 
doctrinales y espirituales con maestros de teología, con Gregorio López, varón contemplativo al que imitará, con santo Toribio de Mogrovejo, arzobispo de Lima, conoció a Martín de Porras, siguió de cerca la labor misional de Francisco Solano o la de los jesuitas Antonio Ruiz de Montoya y Francisco del Castillo. La Ciudad de los Reyes era a menos de un siglo de fundada un lugar en el que el $10 \%$ de la población vestía hábito, había 40 iglesias y capillas y tenía una población cercana a los 25.000 habitantes a la muerte de Rosa, en 1617. Había también muchas beatas visionarias. En su hagiografía los prodigios se inician desde la cuna, ya que a los tres meses el rostro de la niña se transfigura en una rosa, apelativo por el que se la conocerá. En 1606 el dominico limeño Alonso Velásquez le impone el hábito de terciaria dominica. En 1611 toma el nombre de Rosa de Santa María. Según relataron testigos y ella misma explicaba, experimentaba «heridas» de amor de Dios y otros arrobos que hicieron que la Inquisición se fijara en ella y de esta manera fue sometida a un examen de conciencia por el doctor Juan del Castillo, entre otros miembros de la Inquisición de Lima, en 1614. Las expediciones corsarias holandesas asolaron las costas del virreinato en el Callao y amenazaban en una furia iconoclasta destruir los templos de Lima. Los rezos de la población y el ofrecimiento en el Altar de Rosa de Santa María de defender con su cuerpo al Sagrario fueron, según sus biógrafos, los causantes de la retirada de las tropas. En Lima le fue atribuido como milagro. Lo cierto es que unos días antes del ataque previsto murió en su barco el capitán de la flota holandesa, lo que supuso su retirada sin atacar el Callao. Dos años después, en 1617 y pocos meses antes de su muerte, se produjo el llamado desposorio místico con Jesús en un milagro protagonizado por el Niño de la Virgen del Rosario en el altar de la iglesia de santo Domingo. El 24 de agosto murió Rosa y el 1 de septiembre se inició el proceso ordinario de beatificación con las declaraciones de 183 testigos hasta el 7 de abril de 1618. El 17 de mayo de 1630 se inicia el Proceso Apostólico que finalizará en 1632 y aunque según los decretos de Urbano VIII deben pasar cincuenta años de su muerte, el papa Alejandro VI autoriza a que se siga en 1664 el proceso, declarándola beata el 12 de marzo de 1668 el papa Clemente IX y el 12 de abril de 1672 es proclamada santa por Clemente $\mathrm{X}$, reivindicado el origen mestizo de la primera santa americana. Pero es que el 11 de octubre de 1630 el convento de santo Domingo formula una petición para el «título de patrona de su ciudad natal», que el regimiento dejó tibiamente a un lado proponiendo que lo fuera junto a Francisco Solano (español de Montilla, pero misionero en América y muerto en Lima en 1610) y cuyo proceso también estaba en marcha. Hay que hacer notar nuevamente que son una dominica y un franciscano. A Francisco Solano, cuyo proceso comenzó un poco antes que el de Rosa de Lima, lo canonizará Benedicto XIII en 1726. 
La celebración en Roma fue fastuosa con una gran cantidad de repertorios emblemáticos y jeroglíficos en lienzos colgados en la basílica de san Pedro y en la iglesia de Santiago. Todas estas composiciones servirán luego en los ciclos pictóricos americanos posteriores: el prodigio de la rosa en la cuna, la visión de que es Catalina de Siena la que le ofrece el hábito de terciaria, el desposorio místico, arrebatos y desmayos, curaciones milagrosas... ${ }^{131}$. Fue nombrada patrona de Lima y del Perú por Breve papal el 2 de enero de 1669 (patrona más principal de la dicha ciudad de los Reyes y de todo el reino de Perú, con fiesta de precepto, oficio y privilegios de tal) y el 11 de agosto de 1670 es elegida como «Patrona Universal y Principal de toda la América y dominios de España». Trasladados sus reliquias a la iglesia de santo Domingo en Lima, su devoción crece y se fundan conventos al tiempo que se exalta el carácter criollo de la santa, convirtiéndola en símbolo de la Independencia americana declarándola su patrona en 1816.

Sin duda la vida y el culto a Santa Rosa proyectaron una dimensión política y su «desposorio místico» con el Niño de la Virgen del Rosario avaló la misión evangelizadora de la Monarquía española empeñada en hacer tabla rasa con la idolatría indígena. Su actuación contra los holandeses y su defensa de la Eucaristía abundaban en los ideales contrarreformistas de la Casa de Austria, la vinculación con Catalina de Siena augura una nueva espiritualidad que hunde sus raíces en la santa del siglo XIII ${ }^{132}$ y el origen de Rosa afirmaba que el criollo estaba adaptado para la santidad. Mújica considera que con Santa Rosa se produce el mito de la renovación imperial, el mito de santa Rosa como diosa Astrea, la expresión de la Justicia. Siguiendo a Ovidio en la Metamorfosis, Astrea abandona la Tierra al ver que esta es recorrida por ejércitos de hombres criminales cegados de codicia y maldad. Al huir de la Tierra se refugia en el Cielo, transformándose en Virgo, la sexta constelación del Zodiaco. Se profetizó que un niño la devolvería a la Tierra. Durante la Edad Media y el Renacimiento se quiso pensar, siguiendo a Constantino, san Agustín o Dante, que era la Virgen María y el Niño Jesús. América fue un caldo de cultivo idóneo para que florecieran todo tipo de leyendas o construcciones míticas: las predicaciones apocalípticas del dominico español Francisco de la

131. Albornoz, F. de: Breve relación de la solemnissima fiesta de la beatificación de la bienaventurada Rosa de Santa María. Granada, Imprenta Real de Baltasar de Bolívar, 1668; León Pinelo, A. de, Celebridad y fiestas con que la insigne y nobilissima Ciudad de los Reyes solemnizo la beatificación de la bienaventurada Rosa de S. Maria... Lima, 1670; PARRA, J. de: Rosa laureada entre los santos. Madrid, Domingo García Morrás, 1670.

132. MelÉndez, J.: Festiva pompa, culto religioso, veneración reverente, fiesta, aclamación y aplauso a la feliz beatificación de la bienaventurada virgen Rosa de Santa María. Tercera de la Orden de Predicadores. Segunda Catalina Senese de la Iglesia. Primera fragante flor y fruto optimo... Lima, 1671. Nótese la vinculación con santa Catalina de Siena. 
Cruz quemado por la Inquisición limeña en 1578, convencido de que los indios eran las tribus perdidas de Israel o las visiones de franciscanos y dominicos con su retorno a la Edad Dorada del cristianismo. El Papa había otorgado a los españoles el Nuevo Mundo con la idea de formar un orden monárquico universal. En un sermón por la beatificación de Rosa de Lima, dedicado a Carlos II, el dominico cuzqueño fray Juan de Isturrizaga ${ }^{133}$ se refiere a Rosa como la Aurora de Indias, la intercesora de la monarquía universal hispana en el cielo, la que equilibra la Justicia política, la concordia y la paz, con alusión directa a Astrea. La Rosa Astrea indiana era la bendición del imperio americano. Lo más importante de los procesos y de la literatura que se edita en ese contexto es que los criollos descendientes de los conquistadores, los llamados caballeros de Arequipa, se ofrecen a la nueva y primer fruto canonizado, como Aurora del Nuevo Mundo, como esperanza de la nueva clase de españoles americanos, llegando a defender paralelismos entre el culto guadalupano (de la Virgen de Guadalupe) y rosariano (por santa Rosa de Lima). Incluso para los dominicos criollos Rosa representa la defensa de la cuestionada autoridad espiritual de sus frailes nacidos en Perú. Con la santidad de Rosa de Lima se refuerza y se defiende el criollismo novohispano. Tampoco hay que olvidar que hubo intentos de hacer fracasar su subida a los altares. El inquisidor Andrés Gaitán involucró post mortem a Rosa de Lima en 1624 en el marco de la persecución contra las alumbradas que se produjo en aquellos años y ordenó que se retiraran sus reliquias y retratos de la iglesia. A pesar de ello, en sus biografías se resaltan los modelos católicos de piedad femenina y su rigurosa vida penitencial.

Para una correcta comprensión de la difusión del culto y el fervor que santa Rosa consiguió en muchas partes del mundo hay que tener en cuenta las múltiples representaciones de la santa, los grabados y ediciones de retratos y emblemas que tienen como protagonista a la santa limeña y que comenzaron con el retrato solicitado nada más morir al pintor italiano Angelino Medoro. En las fiestas de beatificación y canonización se desplegaron toda una importante serie de jeroglíficos, emblemas y escrituras expuestas en lienzos, grabados y libros que serán el vehículo idóneo para expresar con imágenes las elaboradas composiciones y metáforas. Los paralelismos con la Virgen María son evidentes y a ambas se les considera rosa mística: a santa Rosa segunda rosa mística. Para ello se elaboraron dos grabados similares que recogen ese título marcando ese relación ${ }^{134}$.

133. Isturrizaga, J. de: Sermón en la publicación de la beatificación de la beata Rosa de Santa Maria, patrona del Perú... Madrid, Domingo García Morrás, 1670.

134. Grabado de la Virgen como Rosa Mítica y de Santa Rosa de Lima como Segunda Rosa Mística por los hermanos Joseph Sebastian y Johan Baptist Klamber, en Dorn, F. X.: Litaniae 
Fue Rosa de Lima una santa que rompió los esquemas de la ortodoxia normativa de la Santa Sede al ser nombrada patrona de la Ciudad de los Reyes y del Perú antes de ser canonizada, expresamente prohibido por el decreto de 1630; ya había sido obviado el periodo de tiempo de inicio de los procesos de beatificación y canonización. La explicación puede estar en la necesidad de los territorios americanos españoles de dotarse de una santidad aglutinadora, propia y nacida en esos lugares, vinculada a Órdenes religiosas y también que la poderosa Orden de santo Domingo poseía muchos resortes de poder y muchas influencias en los dicasterios papales.

Como afirma Mújica,

si algo demuestra la hagiografía de Isabel Flores de Oliva es que los santos no sólo son un modelo de piedad cristiana, sino también una fuente inagotable de estudio crítico que permite sondear su influencia como actores sociales... es también la metáfora, el emblema, el mito histórico en perpetua metamorfosis que ejerce una función crucial durante el Virreinato y los inicios de la República en el Perú: la de articular las dramáticas contradicciones internas de una sociedad multiétnica y multiligüística compuesta por españoles, criollos, mestizos, indios y negros ${ }^{135}$.

\section{Conclusiones}

Los sucesivos decretos sobre la forma de llevar adelante los procesos informativo u ordinario y apostólico para la canonización fueron dictados como garantía ante las críticas que se recibían por el culto que se daba a personas que no tenían el título de santos. Los decretos prohibiendo el culto público a una persona antes de su definitiva autorización tras su canonización fueron publicados en 1625, 1631 y 1634. El 23 de marzo de 1630 la Congregación de Ritos dictó otro decreto por el que se declaraba que solo podían ser elegidos como santos patronos aquellos santos venerados como tales por toda la iglesia universal. Para su elección las ciudades o congregaciones debían optar por un santo y tras los oportunos informes e investigaciones a cargo del obispo, la Congregación debía verificar los pasos dados y rechazaba o aprobaba la elección. Que todo el proceso tenía sus excepciones se constata fácilmente, en algunos de los ejemplos traídos al caso en el artículo y muchos otros. Los casos estudiados de Pedro Regalado o Rosa de Lima son evidentes; en ambos casos no se cumplieron los plazos fijados y las autorizaciones a dichas excepciones son diversas, desde la petición consensuada de varios

Lauretanae ad beata virginis caelique regime Mariae. Augsburg, Matthaei Rieger et Filiorum, 1771.

135. Mújica Puntilla, R.: Rosa limensis..., op. cit., Introducción, pp. 43-65, párrafo 2. 
obispados y la ciudad de Valladolid en el caso de Regalado como la necesidad de la clase criolla novohispana de poseer una santa americana con Rosa de Lima que reforzase el territorio con una santidad aglutinadora. En otros casos las decisiones de ciudades sobre los santos patronos se revierten y se corta el proceso hasta que estos estén canonizados y se cumplan los decretos de Urbano VIII. En un caso u otro, tras la proclamación como santo patrono, su día pasa a ser fiesta de precepto según la Bula de 1642. Pero lo más habitual fue que las ciudades, españolas y europeas, salieran de la Edad Media con el patronato de un santo, de un mártir o de una persona santa vinculada al territorio o las Órdenes asentadas en las ciudades. En la Edad Moderna va a suscitarse un nuevo fervor por los mártires y se producirán debates sobre la patria o nación de muchos de ellos generando ríos de tinta y afectando a ciudades con tradición martirial (Zaragoza, Alcalá de Henares, Mérida, Huesca, Valencia, Córdoba...) que buscan generar una identidad propia en torno al santo y los mártires y sentirse beneficiado por su elección. El descubrimientos de cuerpos santos a lo largo de la Edad Moderna y la traslación de reliquias también generarán argumentos para la elección de santos patronos: los casos de san Segundo, san Julián, san Lorenzo...; en todos los casos serán las elites religiosas y políticas y la oligarquía urbana los que presentarán los casos, sufragarán sepulcros y cenotafios, costearán la publicística con la que conseguir mayores devociones. Los cabildos pelearán para tener por patronos a santos antiguos que justifiquen sus pretendidas primacías, como es el caso de los supuestos cuerpos de los varones apostólicos y también de esta manera se entienden los debates en torno al patronazgo de Santiago entre Toledo y Santiago con el añadido de Zaragoza a cuenta de la primacía del Pilar sobre la catedral de La Seo. Las ciudades no tenían un solo santo patrón, se fueron añadiendo y, aunque no llegara a la cantidad que en el siglo Xvir tuvo Nápoles, todas las españolas mantuvieron algunas advocaciones marianas, santos locales y algún otro de cuño moderno que sí cumplió toda la normativa. En el caso de Zaragoza a los patronos Valero y Engracia se añadió la Virgen del Pilar en 1642 como ejemplo claro de la doctrina contrarreformista y la política de la Monarquía Católica.

\section{Bibliografía}

«Fábrica de Santos: España, siglos XVI y XVII», dossier en Revista de Historia Jerónimo Zurita, 85, 2010.

«Le temps des saints. Hagiographie au siécle d'or», dossier en Mélanges de la Casa de Velázquez, 33-2, 2003.

Aina, L.: El milagro de Calanda a nivel histórico. Zaragoza, 1972. 
Ainaga, M. T. y Criado Mainar, J.: «El busto relicario de san Braulio (1456-1461) y la tradición de la venida de la Virgen del Pilar a Zaragoza», Aragón en la Edad media, 20, 2008, pp. 65-84.

Alvar Ezquerra, A.: «Esteban de Garibay: doce claves y alguna relectiones para entender como paralizó la renovación historiográfica española», Revista de Historiografía, 15, 2011, pp. 90-97.

Álvarez Santaló, L. C.: «La escenografía del milagro hagiográfico y la construcción del imaginario colectivo», en Rodríguez Becerra, S. (coord.): Religión y Cultura. Sevilla, Fundación Machado, 1999, vol. 2, pp. 141-172.

AragüÉs, J.: «Los discípulos de Santiago. Tradiciones, equívocos y fabulaciones en la fábrica de un entorno nacional (I)», en Cazal, F., Chauchadis, C. y Herzig, C. (eds.): Pratiques hagiographiques dans l'Espagne du Moyen âge et su Siècle d'Or. Toulouse, CNRS, 2005, pp. 221-233.

AragüÉs, J.: «Los discípulos de Santiago. Tradiciones, equívocos, fabulaciones (II)», en El texto infinito: reescritura y tradición en la Edad Media y en el Renacimiento. Salamanca, SEMYR, 2014, pp. 299-311.

AragüÉs, J.: «Para el estudio del 'Flos sanctorum renacentista'(I), la conformación de un género», en VITSE, M. (ed.): Homenaje a Henri Guerreiro: la hagiografía entre bistoria y literatura en la España de la Edad Media y del Siglo de Oro. Madrid, 2005, pp. 97-147.

Arco, R. del: Catálogo monumental de España. Huesca. Madrid, CSIC, 1942.

Arellano, I. y Vitse, M. (coords.): Modelos de vida en la España del Siglo de Oro. Tomo II. El sabio y el santo. Madrid, Iberoamericana, 2007.

BAÑos, F.: «El conocimiento de la hagiografía medieval castellana. Estado de la cuestión», en VITSE, Marc (ed.): Homenaje a Henri Guerreiro: la bagiografía entre historia y literatura en la España de la Edad Media y del Siglo de Oro. Madrid, 2005, pp. 65-96.

Bejarano, C.: «Santas medievales a los ojos barrocos», Tiempos Modernos, revista electrónica de Historia Moderna, 25, 2012.

Bertelli, S.: «Santos contra santos», en Rebeldes, libertinos y ortodoxos en el Barroco. Barcelona, Península, 1984, pp. 89-110.

Bouza, J. L.: Religiosidad contrarreformista y cultura simbólica del Barroco. Madrid, CSIC, 1990.

Bozóky, E. y Helvétius, A. M. (eds.): Les reliques. Objets, cultes, symboles, Turnhout, Brepols, 1999.

Bozóky, E.: La politique des reliques de Constantin à Saint Louis. París, Beauchesne, 2006.

Cabanes, M. Desamparados: «Inscripciones medievales encontradas en el sepulcro de Santa Engracia y San Lupercio. Paleografía y reliquias», en Santa Engracia. Nuevas aportaciones para la bistoria del monasterio y basílica. Zaragoza, Ayuntamiento de Zaragoza, Gobierno de Aragón y Parroquia de santa Engracia, 2002, pp. 69-82.

Caffiero, M.: La fabrique d'un saint à l'époque des Lumières. París, Éditions de l'EHESS, 2006. 
CAmpo, A. del: «Aproximación a un mapa devocional de Zaragoza en el siglo xIv», Turiaso, XVI, pp. 87-143.

Canalda, J. C.: Los santos Justo y Pastor en España. Alcalá de Henares, Asociación Hijos y Amigos de Alcalá, 1998.

Caro Baroja, J.: Formas complejas de la vida religiosa: religión, sociedad y carácter de la España de los siglos XVI y XVII. Madrid, Akal, 1978.

Caro Baroja, J.: Las falsificaciones en la Historia. Barcelona, 1981.

Carvajal, H. y González-Sarasa, S.: «Los Flos sanctorum: la impronta de la tradición manuscrita en la evolución de un producto editorial», en FERNÁNDEZ RodRÍGUEZ, N. y Fernández Ferreiro, M. (coord.): Literatura medieval y renacentista en España: lineas y pautas. Salamanca, Universidad, 2012, pp. 433-442.

CÁtedra, M.: Un santo para una ciudad. Ensayo de antropología urbana. Barcelona, Ariel, 1997.

Cía Blasco, J.: «Precedentes y orígenes del monasterio jerónimo de Santa Engracia de Zaragoza», Revista de Historia Jerónimo Zurita, 76-77, 2001-2002, pp. 7-90.

Cofiño, I.: «La devoción a los santos y sus reliquias en la iglesia postridentina: el traslado de la reliquia de san Julián a Burgos», Studia Historica: Historia Moderna, 25, 2003, pp. 351-378.

Criado Mainar, J. y Escribano, J. C.: «El busto relicario de san Valero de la Seo de Zaragoza. Noticia de su reforma por Francisco Agüero (ca. 1448-1452)», Boletín del Museo e Instituto Camón Aznar, LIX-LX, Zaragoza, 1995, pp. 119-150.

Criado Mainar, J.: «Los bustos relicarios femeninos en Aragón. 1406-1567», en García Herrero, M. a del C. y Pérez, C.: Las mujeres en la Edad Media: aspectos políticos, socioeconómicos y culturales. Zaragoza, IFC, 2014, pp. 341-368.

Criado Mainar, J.: «La fábrica del monasterio jerónimo de Santa Engracia, 1492-1517», Artigrama, 13, 1998, pp. 253-76.

CUART, B.: «La larga marcha hacia las historias de España en el siglo XVI», en GARcía CÁrcel, R. (coord.): La construcción de las Historia de España. Madrid, Marcial Pons, 2004, pp. 45-126.

Dalla Torre, G.: Santità e diritto. Sondaggi nella storia del diritto canonico. Turín, G. Giappichelli, 1999.

Delehaye, H.: L'oeuvre des Bollandistes à travers trois siécles (1615-1915). Bruselas, Société des Bollandistes, 1959, 2. a ed.

Delpech, F.: L'imaginaire du territorire en Espagne et Portugal (XVIe-XVIIIe siècles). Madrid, Casa de Velázquez, 2008.

Domingo, T. y Casorrán, E.: El milagro de Calanda y otros favores extraordinarios de Nuestra Señora del Pilar. Zaragoza, Comuniter-Cabildo Metropolitano de Zaragoza, 2013.

Domingo, T.: El Milagro de Calanda. Zaragoza, CAI, 2009.

EGIDO, T.: «Hagiografía y estereotipos de santidad contrarreformista (La manipulación de san Juan de la Cruz)», Cuadernos de Historia Moderna, 25, 2000, pp. 61-86.

Egido, T.: San Pedro Regalado. Valladolid, Diputación de Valladolid, 1983. 
Egido, T.: «Procesos de beatificación y canonización de san Pedro Regalado», Archivo Ibero-Americano, 12, 1920, pp. 5-20.

Escribano Paño, M. V. y Fatás, G.: La Antigüedad tardía (287-714). Zaragoza, CAI, 2001. Escribano PaÑo, M. V.: Los primeros testimonios cristianos en Aragón, en Aragón antiguo. Fuentes para su estudio. Zaragoza, Universidad-Gobierno de Aragón, 2013.

Español, F. y Fité, F. (eds.): Hagiografía peninsular en els segles medievals. Lleida, Univeritat, 2008.

Estella, E.: El milagro de Calanda, estudio histórico crítico. Zaragoza, 1951.

García CÁrcel, R. (coord.): La construcción de las Historia de España. Madrid, Marcial Pons, 2004.

García Hernán, E.: "Construcción de las historias de España en los siglos XVII y XVIII», en García CÁrcel, R. (coord.): La construcción de las Historia de España. Madrid, Marcial Pons, 2004. pp. 127-194, p. 143

García Herrero, M. ${ }^{a}$ del C. y Criado, J.: «Orosia y Engracia, princesas santas de la montaña y del llano», en García Herrero, M. del C.: Artesanas de vida. Zaragoza, IFC, 2009, pp. 261-312.

Gascón, A. y Briongos, Á.: El milagro del cojo de Calanda. La génesis de un mito. Zaragoza, Geoda, 2015.

Geary, P. J.: Furta sacra. Thefts of Relics in the Central Middle Ages. Princenton University Press, 1978.

Godding, R., Johssant, B., Leques, ., VRiendt, F. de y Straeten J. van der: Bollandistes, saints et legends. Quatre siécles de recherche hagiographique. Bruselas, Société des Bollandistes, 2007.

Gómez Zorraquino, J. I.: «Los santos patronos y la identidad de las comunidades locales», en E. SERrano (ed.): «Fábrica de santos. España, siglos XVI-XVII», Jerónimo Zurita, 85, 2010, pp. 39-74.

Gómez Zorraquino, J. I.: Los santos Lorenzo y Orencio se ponen al servicio de las «tradiciones». Siglo XVII. Huesca, IEA, 2007.

GonzÁlez Lopo, D. L.: «El papel de las reliquias en las prácticas religiosas de los siglos xvil y xviıI», en Álvarez Santaló, L. Carlos y Cremades Griñán, C. (eds.): Mentalidad e ideología en el Antiguo Régimen. Actas de las II Reunión Científica de la Asociación Española de Historia Moderna. Murcia, Universidad, Vol. II, 1993, pp. 247-260.

González Lopo, D. L.: «San Rosendo: de santo admirable a santo imitable. Un análisis comparativo de hagiografía medieval y barroca», Rudesindus, 1, 2007, pp. 17-44.

González Lopo, D.: «Los nuevos modos de la hagiografía contrarreformista», Memoria Ecclesiae, 24, 2004, pp. 609-632.

Gotor, M.: Chiesa e santità en l'Italia moderna. Roma-Bari, Laterza, 2004.

Gotor, M.: I Beati del Papa. Santità, Inquisizione e obbedienza in età moderna. Florencia, Leo S. Olschki, 2002. 
Guazzelli, G. A., Michetti, R. y Scorza, F. (eds.): Cesare Baronio tra santità e scrittura storica. Atti del Colloquio Internazionale di Studi (Roma, 25-27 gingno 2007). Barcelona, Roma, Viella, 2012.

Gutiérrez Lasanta, F.: Historia de la Virgen del Pilar. 10 vols. Zaragoza, El Noticiero, 1971-1987.

Hermann-Mascard, N.: Les reliques des saints. Formation coutoumière d'un droit. París, Klincksieck, 1975.

IвÁÑEZ, J.: La portada escultórica de Santa Engracia. Aproximación histórica y breve estudio artístico e iconográfico. Zaragoza, IFC, 2004.

Jarque, E.: Los procesos de limpieza de sangre en la Zaragoza de la Edad Moderna. Zaragoza, Ayuntamiento, 1983.

Jiménez Monteserín, M.: Vere pater pauperum. El culto de San Julián en Cuenca. Cuenca, Diputación Provincial,1999.

Jiménez Zamora, V.: "Culto de Soria a san Saturio y significado religioso de su ermita», Revista de Soria, 14, 1996, pp. 65-76.

KagAN, R.: «La corografía en la Castilla moderna: género, historia, nación», en Arellano, I., Pinillos, M. C., Serralta, F. y Vitse, M. (eds.): Studia Aurea. Actas III Congreso de la AISO, Toulouse-Pamplona, 1996, 1, pp. 79-91.

KagAn, R.: Los cronistas y la Corona. La política de la Historia en la España de las edades Media y Moderna. Madrid, Marcial Pons, 2010.

Lacarra, M. ${ }^{a}$ del C.: «La devoción a Santa María del Pilar de Zaragoza durante la Baja Edad Media», en El Pilar es la columna. Historia de una devoción. Zaragoza, Gobierno de Aragón y Ayuntamiento de Zaragoza, 1995, pp. 23-46.

Madre de Dios, E. de la y Steggink, O.: Tiempo y vida de santa Teresa. Madrid, Biblioteca de Autores Cristianos.

Magallón, A. I. y Martín, J. C.: «La leyenda de la venida de la Virgen a Zaragoza (BHL 5388): Edición crítica y estudio", Hagiographica, XXI, 2014, pp. 53-84.

Márquez Villanueva, F.: Santiago: trayectoria de un mito. Barcelona, Bellaterra, 2004. MArtínez, J.: Jaime II de Aragón: su vida familiar. Barcelona, CSIC, 1948, t. II, pp. 235-236. Memoria Ecclesiae, 21, 2002. Monográfico sobre reliquias.

Mestre, A.: «Conciencia histórica e Historiografía», en Jover, J. M. (ed.): Historia de España. Vol. XXXI-1, Madrid, Espasa Calpe, 1987, pp. 302-345.

Mestre, A.: Humanismo y crítica histórica en los ilustrados alicantinos. Alicante, sucesor de Suchs y Serra, 1980.

Morte, C.: «El patrocinio artístico de las clases privilegiadas: prestigio y devoción durante el Renacimiento en Aragón», en IвÁÑEz, Javier (coord. y ed.): Del mecenazgo a las nuevas formas de promoción artística. Zaragoza, PUZ, 2017, pp. 45-102, pp. 71-72.

Mostalac, A.: «Novedades sobre el sarcófago de la Receptio animae, tras su restauración y extracción del arcosolio del muro de la epístola, de la basílica menor de Santa Engracia", en Santa Engracia. Nuevas aportaciones para la historia del monasterio y basílica. Zaragoza, Ayuntamiento de Zaragoza, Gobierno de Aragón y Parroquia de santa Engracia, 2002, pp. 42-58. 
Mújica Puntilla, R.: Rosa limensis: mística, política e iconografía en torno a la patrona de América. México, México, FCE-IFEA-Centro de Estudios Mexicanos y Centroamericanos, 2004. [1. Edición].

MuÑoz, F.: «La construcción de una vida edificante. Fray Ignacio de Santibáñez, arzobispo de Manila en 1598», en Serrano, E. (ed.): De la tierra al cielo. Zaragoza, IFC, 2013, pp. 117-133.

Muñoz, F.: «Un catálogo de santidad. La segunda parte de la Crónica de la provincia franciscana de Burgos», en Atienza, Á. (ed.): Iglesia Memorable. Crónicas, historias, escritos... a mayor gloria. Madrid, Sílex, 2012, pp. 323-341.

Nalle, S. T.: «A Saint for All Seasons: The Cult of San Julián», en Cruz, Anne J. y Perry, Mary E. (eds.): Culture and Control in Counter-Reformation Spain. MinneapolisOxford, 1992, pp. 25-50.

Nalle, S. T.: «Desde el olvido a la fama: el culto a san Julián en los siglos Xvi y xviI», Almud. Revista de Estudios de Castilla La Mancha, 1, 1981, pp. 25-41.

Pérez, J.: Teresa de Ávila y la España de su tiempo. Madrid, Algaba, 2007.

Polo Carrasco, José: Los juramentos inmaculistas en Zaragoza, 1617-1619. Zaragoza, Caja de Ahorros de Zaragoza, Aragón y Rioja, 1987.

Postigo Vidal, J.: La vida fragmentada. Experiencias y tensiones cotidianas en Zaragoza (Siglos XVII y XVIII). Zaragoza, Institución Fernando el Católico, 2015.

Quiles, F.: «La invención de la forma y la concreción del gesto. La hagiografía creada para la Sevilla barroca», en Carlos Varona, M. ${ }^{a}$ C. de, Civil, P., Pereda, F. y Vincent-Cassy, C. (coords.): La imagen religiosa en la Monarquía hispánica. Usos y espacios. Madrid, Casa de Velázquez, 2008, pp. 135-149.

Ramallo, G.: «Reactivación del culto a las reliquias en el barroco. La catedral de Oviedo y su Cámara Santa en 1639», Liño, 11, pp. 77-91.

Rausell, H.: «La espiritualidad de Pedro Antonio Beuter: erasmismo y corrientes de reforma», Estudis, 23, 1997, pp. 41-75.

Reliquias políticas I. Cuerpos santos de Antiguo Régimen, Coloquio en la Casa de Velázquez, 19-20 de marzo de 2015.

Rey, O.: «La disputa del patronazgo de la Monarquía, ¿Santiago o santa Teresa?», en Martínez Millán, J. y Visceglia, M. A. (eds.): La Monarquía de Felipe II. La Casa del Rey. Madrid, Mapfre, 2007-2008, Vol. I., pp. 227-246.

Rey, O.: Los mitos del apóstol Santiago, Santiago de Compostela. Nigratea, 2006.

Rey, O.: «Teresa, patrona de España», Hispania Sacra, LXVII, 2015, pp. 531-573.

Río, A. del: Teatro y entrada triunfal en la Zaragoza del Renacimiento (Estudio de la "Representación del Martirio de santa Engracia» de Fernando Basurto en su marco festivo). Zaragoza, Ayuntamiento, 1988.

Río, M. J. del: «Agiografia e cronaca di una capitale incerta (Madrid e Isidro labrador, 1590-1620)», en Fiume, G. (ed.): Il santo patrono e la città. San Bernedetto il Moro: culti, devozioni, strategie di età moderna. Venecia, Marsilio, 2000, pp. 45-67.

Río, M. ${ }^{a}$ J. del: Madrid, urbs regia. La capital ceremonial de la Monarquía Católica. Madrid, Marcial Pons, 2000. 
Rowe, E. K.: Saint and Nation: Teresa of Avila, Santiago, and Plural Identities in Early Modern Spain. Penn State University Press, 2011.

SAEZ, R.: «El culto a san Isidro labrador o la invención y triunfo de una amplia operación político religiosa (1580-1622)», en VITSE, M. (ed.): Homenaje a Henri Guerreiro: la hagiografía entre historia y literatura en la España de la Edad Media y del Siglo de Oro. Madrid, Iberoamericana, 2005, pp. 1033-1045.

Sallman, J.-M.: Santi barocchi. Modelli di santità. Pratiche devozionali e comportamenti religiosi nel regno di Napoli dal 1540 al 1750. Lecce, Argo, 1996.

SÁnchez FerRA, A. J.: «El logroñés Jerónimo Román y su obra sobre las Repúblicas del mundo», Cuadernos de Investigación: Historia, T. 10, fasc. 1, 1984, pp. 307-316.

SÁnCHEz Ferro, P.: «La ciudad en procesión: estudio sobre traslación de reliquias (Centrado en el ejemplo de san Frutos, patrón de Segovia)», Espacio, Tiempo y Forma, Serie IV Historia Moderna, T. 12, 1999, pp. 47-65.

Sancho Izquierdo, M.: El milagro de Calanda. Zaragoza, 1940.

Santa Teresa, S. de: Historia del Carmen descalzo en España, Portugal, y América. Burgos, Monte Carmelo, 1935-1953, 15 Vols.

Serrano Martín, E., «Silentium facite. El final de la polémica y el discurso en torno a la Virgen del Pilar», Hispania, 248, 2014, pp. 687-714.

Serrano Martín, E.: «Huesos de santo. Santa Engracia y la entrega de reliquias en las entradas reales zaragozanas», en PeÑA, M. (ed.), La vida cotidiana en el mundo bispánico (Siglos XVI-XVIII). Madrid, Abada, 2012, pp. 407-24.

Serrano Martín, E.: El Pilar, la historia y la tradición. La obra erudita de Luis Díez de Aux (1562-ca. 1630). Zaragoza, Mira, 2014.

TAusiet, M.: El dedo robado. Reliquias imaginarias en la España moderna. Madrid, Abada editores, 2013.

VALDERAs, A.: Bibliografía histórica leonesa: Juan de Ferreras García (1652/1735): estudio bio-bibliográfico. León, Universidad, 2000.

VINCENT-CAssy, C.: «La propagande hagiographique des villes espagnoles au Xvire siècle. Le cas de Sainte Juste et de Sainte Rufine, patrones de Séville», Melanges de la Casa de Velázquez, 33-2, 2003, pp. 97-130. 